University of Wollongong

Research Online

Australian Institute for Innovative Materials -

Papers

Australian Institute for Innovative Materials

$1-1-2018$

Heterostructure Manipulation via in Situ Localized Phase Transformation for High-Rate and Highly Durable Lithium Ion Storage

Junnan Hao

University of Wollongong, jh845@uowmail.edu.au

Jian Zhang

Changsha University of Science And Technology

Guanglin Xia

University of Wollongong, guanglin@uow.edu.au

Yajie Liu

University of Wollongong, yl327@uowmail.edu.au

Yang Zheng

University of Wollongong, yz966@uowmail.edu.au

See next page for additional authors

Follow this and additional works at: https://ro.uow.edu.au/aiimpapers

Part of the Engineering Commons, and the Physical Sciences and Mathematics Commons

Research Online is the open access institutional repository for the University of Wollongong. For further information contact the UOW Library: research-pubs@uow.edu.au 


\title{
Heterostructure Manipulation via in Situ Localized Phase Transformation for High-Rate and Highly Durable Lithium Ion Storage
}

\author{
Abstract \\ Recently, heterostructures have attracted much attention in widespread research fields. By tailoring the \\ physicochemical properties of the two components, creating heterostructures endows composites with \\ diverse functions due to the synergistic effects and interfacial interaction. Here, a simple in situ localized \\ phase transformation method is proposed to transform the transition-metal oxide electrode materials into \\ heterostructures. Taking molybdenum oxide as an example, quasi-core-shell \\ Mo03@Mo02heterostructures were successfully fabricated, which were uniformly anchored on reduced \\ graphene oxide ( $\mathrm{rGO}$ ) for high-rate and highly durable lithium ion storage. The in situ introduction of the \\ $\mathrm{MoO} 2$ shell not only effectively enhances the electronic conductivity but also creates \\ Mo03@Mo02heterojunctions with abundant oxygen vacancies, which induces an inbuilt driving force at \\ the interface, enhancing ion/electron transfer. In operando synchrotron X-ray powder diffraction has \\ confirmed the excellent phase reversibility of the MoO2shell during charge/discharge cycling, which \\ contributes to the excellent cycling stability of the MoO3@Mo02/rGO electrode (1208.9 mAh \\ $\mathrm{g}$-1 remaining at $5 \mathrm{~A} \mathrm{~g}-1$ after 2000 cycles). This simple in situ heterostructure fabrication method provides \\ a facile way to optimize electrode materials for high-performance lithium ion batteries and possibly other \\ energy storage devices.

\section{Disciplines} \\ Engineering | Physical Sciences and Mathematics

\section{Publication Details} \\ Hao, J., Zhang, J., Xia, G., Liu, Y., Zheng, Y., Zhang, W., Tang, Y., Pang, W. \& Guo, Z. (2018). Heterostructure \\ Manipulation via in Situ Localized Phase Transformation for High-Rate and Highly Durable Lithium lon \\ Storage. ACS Nano, 12 (10), 10430-10438.

\section{Authors} \\ Junnan Hao, Jian Zhang, Guanglin Xia, Yajie Liu, Yang Zheng, Wenchao Zhang, Yongbing Tang, Wei Kong \\ Pang, and Zaiping Guo
}




\title{
Heterostructure Manipulation via In-Situ Localized Phase Transformation for High- Rate and Highly Durable Lithium Ion Storage
}

\author{
Junnan $\mathrm{Hao}^{\dagger}$, Jian Zhang ${ }^{\ddagger}$, Guanglin Xia ${ }^{\dagger}$, Yajie Liu', Yang Zheng ${ }^{\dagger}$, Wenchao Zhang ${ }^{\dagger}$, \\ Yongbing Tang ${ }^{*}$, Wei Kong Pang ${ }^{\dagger}$, Zaiping Guo*广
}

\footnotetext{
${ }^{\dagger}$ Institute for Superconducting \& Electronic Materials, School of Mechanical, Materials and Mechatronics Engineering, University of Wollongong, Wollongong, NSW 2522, Australia

${ }^{\ddagger}$ College of Automotive and Mechanical Engineering, Changsha University of Science and Technology, Changsha 410114, China

$\S$ Functional Thin Films Research Center; Shenzhen Institutes of Advanced Technology, Chinese Academy of Sciences, Shenzhen 518055, China

Corresponding Author: ${ }^{*}$ tangyb@siat.ac.cn; zguo@uow.edu.au
}

\begin{abstract}
:
Recently, heterostructures have attracted much attention in widespread research fields. By tailoring the physicochemical properties of the two components, creating heterostructures endows composites with diverse functions due to the synergistic effects and interfacial interaction. Here, a simple in-situ localized phase transformation method is proposed to transform the transition metal oxide electrode materials into heterostructures. Taking molybdenum oxide as an example, quasi-core-shell $\mathrm{MoO}_{3} @ \mathrm{MoO}_{2}$ heterostructures were successfully fabricated, which were uniformly anchored on reduced graphene oxide (rGO) for high-rate and highly durable lithium ion storage. The in-situ introduction of the $\mathrm{MoO}_{2}$ shell not only effectively enhances the electronic conductivity, but also creates $\mathrm{MoO}_{3} @ \mathrm{MoO}_{2}$ heterojunctions with abundant oxygen vacancies, which induces an inbuilt driving force at the interface, enhancing ion/electron transfer. In-operando synchrotron X-ray powder
\end{abstract}


diffraction has confirmed the excellent phase reversibility of the $\mathrm{MoO}_{2}$ shell during charge/discharge cycling, which contributes to the excellent cycling stability of the $\mathrm{MoO}_{3} @ \mathrm{MoO}_{2} / \mathrm{rGO}$ electrode (1208.9 mAh g ${ }^{-1}$ remaining at $5 \mathrm{~A} \mathrm{~g}^{-1}$ after 2000 cycles). This simple in-situ heterostructure fabrication method provides a facile way to optimize electrode materials for high-performance lithium ion batteries and possibly other energy storage devices.

KEYWORDS: heterostructure; in-situ localized phase transformation; $\mathrm{MoO}_{3} @ \mathrm{MoO}_{2}$; oxygen vacancies; interfacial interaction; DFT calculation; lithium ion batteries 
Heterostructures can be formed by modulating different compositions and/or doping to enable passivation of interfaces, where the electronic band structure near the interface will be changed according to the electrostatics. ${ }^{1}$ Because of their interface effects, heterostructures with distinct functionality often exhibit enhanced performance in many electronic devices, including solar cells, ultrathin photodetectors, semiconductor lasers, and tunneling transistors. ${ }^{2-4}$ It has been claimed that building heterostructures though coupling components with different electronic energy band gaps will improve the surface reaction kinetics and facilitate charge transport due to the benefit of the internal electric field at the interface. For instance, fast ion conduction has been demonstrated in nanometer-scale $\mathrm{CaF}_{2} / \mathrm{BaF}_{2}$ heterostructures. ${ }^{5}$ Benefiting from the synergistic effects, two-dimensional (2D)-mesoporouscarbon/MoS 2 heterostructures exhibited outstanding cycling stability and high-rate performance in lithium ion batteries (LIBs). ${ }^{6}$ Due to integration of the merits of the different components and reversible electron/ion transport at the interface, $\mathrm{SnO}_{2} / \mathrm{MXene}$ and $\mathrm{TiO}_{2} / \mathrm{MXene}$ heterostructures showed high capacity and extraordinary high-rate performance for $\mathrm{Li}$ ion storage. ${ }^{7}$ Inspired by previous research, we believe that transition metal oxide heterostructures can be manipulated via in-situ localized phase transformation as electrode materials with excellent performance in energy storage devices.

Owing to its high theoretical capacity $\left(1117.3 \mathrm{mAh} \mathrm{g}^{-1}\right), \alpha-\mathrm{MoO}_{3}$ with a bilayer structure has attracted much attention as an attractive candidate anode for LIBs. ${ }^{8}$ The Li storage performance of $\mathrm{MoO}_{3}$ is severely restricted, however, by its sluggish $\mathrm{Li}$ ion diffusion kinetics. ${ }^{9}$ A variety of strategies have been claimed to enhance the kinetic of $\mathrm{MoO}_{3}{ }^{10}$ Nanostructuring is one of the most widespread strategies, and various nanostructured forms of $\mathrm{MoO}_{3}$, including nanowires, nanorods, and nanosheets, have been reported to boost the $\mathrm{Li}$ storage kinetics. ${ }^{11}$ Unfortunately, self-aggregation and the volume expansion of nanomaterials severely limit the beneficial effects of nanostructuring. ${ }^{12}$ Introducing a conductive matrix into 
$\mathrm{MoO}_{3}$ is another common strategy to enhance the electronic conductivity of $\mathrm{MoO}_{3} .{ }^{13}$ The main drawback of this strategy, however, is that only near-surface materials, which have intimate contact with the conductive matrix, could experience enhanced electronic conductivity. ${ }^{14}$ Consequently, achieving $\mathrm{MoO}_{3}$-based materials with excellent high-rate performance and cycling stability still remains a huge challenge. ${ }^{15-19}$

Monoclinic $\mathrm{MoO}_{2}$, although having lower capacity (837.6 $\mathrm{mAh} \mathrm{g}^{-1}$ ) compared with $\alpha-\mathrm{MoO}_{3}$, is also an anode candidate for LIBs, resulting from its metallic electrical conductivity and facile ion transport properties. ${ }^{13,20}$ Based on the solid-state reaction kinetics, the transformation from $\alpha-\mathrm{MoO}_{3}$ to $\mathrm{MoO}_{2}$ preferentially occurs in a perpendicular direction to the crystalline layers of $\alpha-\mathrm{MoO}_{3}$ during thermal reduction ([010] direction), and thus, it is believed that $\alpha-\mathrm{MoO}_{3} / \mathrm{MoO}_{2}$ heterojunctions could be created, which could be an effective way to achieve molybdenum oxide electrodes with high electrical conductivity and good structural stability, as well as high capacity. ${ }^{21-22}$ In addition, oxygen vacancies formed at the heterointerface could create atomic defects, structural distortion, and an unbalanced charge distribution at the interface, which would provide an inbuilt charge-transfer driving force, ${ }^{23-24}$ facilitating interfacial electron transport and accelerating the $\mathrm{Li}^{+}$ion diffusion kinetics in the electrode. $^{15}$

Herein, a facile localized phase transformation strategy was adopted for in-situ fabrication of $\mathrm{MoO}_{2}$ coated $\alpha-\mathrm{MoO}_{3}$ heterostructures, which were homogeneously decorated on reduced graphene oxide $\left(\mathrm{MoO}_{3} @ \mathrm{MoO}_{2} / \mathrm{rGO}\right)$ sheets. The homogeneous coating of $\mathrm{MoO}_{2}$ and the uniform distribution of $\mathrm{MoO}_{3} @ \mathrm{MoO}_{2}$ heterostructures on rGO could effectively improve the electrical conductivity. The oxygen vacancies generated at the interface of $\mathrm{MoO}_{3}$ and $\mathrm{MoO}_{2}$ with the reduction of $\mathrm{MoO}_{3}$ create desirable interfacial effects, which was further confirmed by density functional theory (DFT) calculations. In-operando synchrotron X-ray powder diffraction (XRPD) further verified the high reversibility of the $\mathrm{MoO}_{2}$ shell during cycling, 
which helps to enhance the cycling stability. Thanks to these structural advantages, the $\mathrm{MoO}_{3} @ \mathrm{MoO}_{2} / \mathrm{rGO}-500$ electrode delivered a high capacity of $1340.0 \mathrm{mAh} \mathrm{g}^{-1}$ at $100 \mathrm{~mA} \mathrm{~g}^{-1}$ and outstanding cycling stability, with a capacity of $1208.9 \mathrm{mAh} \mathrm{g}^{-1}$ remaining after 2000 cycles at $5 \mathrm{~A} \mathrm{~g}^{-1}$. This work demonstrates an effective way to enhance the Li storage kinetics via the construction of interfaces and the introduction of heterostructures by in-situ oxidation/reduction. The proposed heterostructure manipulation strategy could also be extended to other transition metal oxide electrodes for energy storage and conversion.

\section{RESULTS AND DISCUSSION}

One-step in-situ phase transformation was employed to prepare $\mathrm{MoO}_{3} @ \mathrm{MoO}_{2} / \mathrm{rGO}$ with $\left(\mathrm{NH}_{4}\right)_{6} \mathrm{Mo}_{7} \mathrm{O}_{24}$ chosen as the Mo source. To investigate the phase transformation of $\left(\mathrm{NH}_{4}\right)_{6} \mathrm{Mo}_{7} \mathrm{O}_{24} /$ graphene oxide $(\mathrm{GO})$ during the calcining process, thermogravimetric analysis (TGA) was conducted in argon (Figure 1a) and air flow (Figure S1 in the Supporting Information), respectively. Four weight loss regions can be observed in Figure 1a: the weight losses in the temperature range of $50-180{ }^{\circ} \mathrm{C}$ and $180-300{ }^{\circ} \mathrm{C}$ originate from the removal of interlayer moisture and the decomposition of $\left(\mathrm{NH}_{4}\right)_{6} \mathrm{Mo}_{7} \mathrm{O}_{24}$, respectively. ${ }^{25}$ The following stage from 300 to $420{ }^{\circ} \mathrm{C}$ corresponds to the removal of oxygen-containing functional groups from the GO sheets. Subsequently, $\alpha-\mathrm{MoO}_{3}$ is gradually reduced into $\mathrm{MoO}_{2}$ from $420{ }^{\circ} \mathrm{C}$ and completely converted into $\mathrm{MoO}_{2}$ when the temperature reaches $550{ }^{\circ} \mathrm{C}$. This result validates the possibility of fabricating $\mathrm{MoO}_{3} @ \mathrm{MoO}_{2}$ heterojunctions through controlling the heattreatment temperature, as evidenced by the X-ray diffraction (XRD) results (Figure 1b). The product synthesized at $400{ }^{\circ} \mathrm{C}$ (denoted as $\left.\mathrm{MoO}_{3} / \mathrm{rGO}-400\right)$ has only characteristic peaks corresponding to $\mathrm{MoO}_{3}{ }^{26}$ While characteristic peaks assigned to monoclinic $\mathrm{MoO}_{2}$ appear with weakening of the peak intensity of $\alpha-\mathrm{MoO}_{3}$ simultaneously after thermal annealing of the samples at 450 and $500{ }^{\circ} \mathrm{C}\left(\mathrm{MoO}_{3} @ \mathrm{MoO}_{2} / \mathrm{rGO}-450\right.$ and $\mathrm{MoO}_{3} @ \mathrm{MoO}_{2} / \mathrm{rGO}-500$, respectively), indicating both samples contain the $\mathrm{MoO}_{3}$ and $\mathrm{MoO}_{2}$ phase. On further 
increasing the heating temperature to $600{ }^{\circ} \mathrm{C}$, only $\mathrm{MoO}_{2}$ peaks can be observed with the complete disappearance of peaks for $\mathrm{MoO}_{3}\left(\mathrm{MoO}_{2} / \mathrm{rGO}-600\right){ }^{20}$

X-ray photoelectron spectroscopy (XPS) measurements were further adopted to characterize the oxidation state of molybdenum in different samples (Figure S2 and Figure 1c). The Mo $3 \mathrm{~d}$ spectrum of $\mathrm{MoO}_{3} / \mathrm{rGO}-400$ (Figure S2a) is mainly occupied by $\mathrm{Mo}^{6+}$ with a spin-orbit doublet peaks at binding energies of $232.3 \pm 0.1$ and $236.0 \pm 0.1 \mathrm{eV}^{27-28}$ After heating to $600{ }^{\circ} \mathrm{C}, 3 \mathrm{~d}^{4+}{ }_{3 / 2}$ and $3 \mathrm{~d}^{4+} 5 / 2$ peaks belonging to $\mathrm{MoO}_{2}$ could be observed (Figure S2b). ${ }^{29}$ By comparison, the Mo 3d spectrum of $\mathrm{MoO}_{3} @ \mathrm{MoO}_{2} / \mathrm{rGO}-500$ reveals the simultaneous presence of characteristic peaks belonging to $\mathrm{Mo}^{4+}$ and $\mathrm{Mo}^{6+}$, and the peak intensity of $\mathrm{Mo}^{6+}$ is increased after etching the surface with argon plasma to remove the surface layer (Figure 1c). ${ }^{15}$ Further calculations demonstrated that the content of $\mathrm{Mo}^{6+}$ increased from $33.4 \%$ to $39.8 \%$ after argon plasma etching (Table S1), which indicates that the majority of the $\mathrm{MoO}_{3}$ was reduced to $\mathrm{MoO}_{2}$, with the $\mathrm{MoO}_{3}$ occupying the inner part of the heterostructure, while the $\mathrm{MoO}_{2}$ is mainly located in the outer part (schematic illustration shown in Figure S3).

The morphology of $\mathrm{MoO}_{3} @ \mathrm{MoO}_{2} / \mathrm{rGO}$ and the phase transfer process to form the $\mathrm{MoO}_{3} @ \mathrm{MoO}_{2}$ heterostructure in $\mathrm{MoO}_{3} @ \mathrm{MoO}_{2} / \mathrm{rGO}-500$ were further investigated by scanning electron microscopy (SEM) and transmission electron microscopy (TEM). It is obvious that the small nanosheets of $\mathrm{MoO}_{3} @ \mathrm{MoO}_{2}$ are uniformly anchored on the rGO sheets, as shown in Figure 1d. The $\mathrm{MoO}_{3} @ \mathrm{MoO}_{2}$ heterostructured particles, however, suffer from serious aggregation without rGO support (Figure S4). The TEM results further verified the homogeneous dispersion of lamellar $\mathrm{MoO}_{3} @ \mathrm{MoO}_{2}$ heterostructures with widths of $\sim 200 \mathrm{~nm}$ (Figure 1e). Atomic force microscopy (Figure 1f) confirmed that the thickness of the $\mathrm{MoO}_{3} @ \mathrm{MoO}_{2}$ nanosheets is $\sim 5 \mathrm{~nm}$. These $\mathrm{MoO}_{3} @ \mathrm{MoO}_{2}$ nanosheets guarantee facile strain relaxation and help to alleviate the volume expansion of the $\mathrm{MoO}_{3}$ inside. ${ }^{30}$ In comparison, $\mathrm{MoO}_{3} @ \mathrm{rGO}-400$ and $\mathrm{MoO}_{2} / \mathrm{rGO}-600$ show similar morphology (Figures S5a 
and S6a). The high-resolution TEM (HRTEM) image of $\mathrm{MoO}_{3} @ \mathrm{rGO}-400$ (Figure S5c) shows lattice spacing of $0.326 \mathrm{~nm}$, which can be assigned to the (021) crystal planes of $\alpha$ $\mathrm{MoO}_{3}$. This agrees well with the selected area electron diffraction (SAED) pattern (Figure S5b). In the HRTEM image of $\mathrm{MoO}_{2} / \mathrm{rGO}-600$, a uniform lattice spacing of $0.342 \mathrm{~nm}$, which corresponds to the (011) planes of monoclinic $\mathrm{MoO}_{2}$, can be observed (Figure S6c). For the $\mathrm{MoO}_{3} @ \mathrm{MoO}_{2} / \mathrm{rGO}-500$ sample, however, the corresponding SAED pattern (Figure 1k) confirms the polycrystalline nature of $\mathrm{MoO}_{3} @ \mathrm{MoO}_{2}$ heterojunctions, including both $\mathrm{MoO}_{2}$ and $\mathrm{MoO}_{3}$ phases. Furthermore, a lattice spacing of $0.342 \mathrm{~nm}$, characteristic of the $(011)$ planes of $\mathrm{MoO}_{2}$, can be observed on the boundary and it crosses the whole surface (Figure 11), whereas the internal lattice spacing $(0.326 \mathrm{~nm})$ corresponds to the $(021)$ planes of $\alpha$ $\mathrm{MoO}_{3}$, revealing that $\mathrm{MoO}_{2}$ is generated on the border and at the surface of $\mathrm{MoO}_{3}$ via in-situ localized phase transformation, which is consistent with the reduction mechanism of $\alpha$ $\mathrm{MoO}_{3} .{ }^{31}$ The localized phase transformation and formation of $\mathrm{MoO}_{2}$ at the edge and surface could shorten the electron/ion transfer pathways in the inner $\mathrm{MoO}_{3}$, thus not only enhancing the electrical conductivity, but also creating $\mathrm{MoO}_{3} @ \mathrm{MoO}_{2}$ heterostructures, which can tailor the physicochemical characteristics of the two building blocks and endow $\mathrm{MoO}_{3} @ \mathrm{MoO}_{2}$ with excellent performance due to the synergistic effects. ${ }^{32}$ More interestingly, according to the reduction mechanism of $\alpha-\mathrm{MoO}_{3}$, lattice oxygen $\mathrm{O}_{(3)}$ on the (010) facet was reduced, resulting in oxygen vacancies at the interface of $\mathrm{MoO}_{3}$ and $\mathrm{MoO}_{2}$, as verified by electron paramagnetic resonance (EPR) (Figure S7). ${ }^{33}$ The oxygen vacancies at the interface cause an unbalanced charge distribution, which helps to promote interfacial charge transfer. ${ }^{34-35}$

To compare the $\mathrm{Li}$ storage performance of $\mathrm{MoO}_{3}, \mathrm{MoO}_{2}$, and $\mathrm{MoO}_{3} @ \mathrm{MoO}_{2}$ heterostructures, $\mathrm{MoO}_{3} / \mathrm{rGO}, \quad \mathrm{MoO}_{3} @ \mathrm{MoO}_{2} / \mathrm{rGO}$, and $\mathrm{MoO}_{2} / \mathrm{rGO}$ electrodes were investigated using discharge--charge cycling and cyclic voltammograms $(\mathrm{CVs})$ in coin cells. Figure $2 \mathrm{a}$ and Figures S8, 9 show the typical discharge-charge curves of the different electrodes at $100 \mathrm{~mA}$ 
$\mathrm{g}^{-1}$. In the case of $\mathrm{MoO}_{3} / \mathrm{rGO}-400$ electrode, only an obvious discharge platform below $0.4 \mathrm{~V}$ can be observed, which is consistent with its CV curves (Figure S10a). The discharge capacity of $\mathrm{MoO}_{3} / \mathrm{rGO}-400$ is $853.1 \mathrm{mAh} \mathrm{g}^{-1}$, still much lower than the theoretical specific capacity of $\alpha-\mathrm{MoO}_{3}$. The $\mathrm{MoO}_{3} @ \mathrm{MoO}_{2} / \mathrm{rGO}-500$ and $\mathrm{MoO}_{2} / \mathrm{rGO}-600$ electrodes exhibit three discharge plateaus between $1.0 \mathrm{~V}$ and $2.0 \mathrm{~V}$, indicating the phase transitions of $\mathrm{MoO}_{2}$ in the $\mathrm{Li}$ insertion process from the original monoclinic to the orthorhombic phase and then from the orthorhombic to the monoclinic phase. ${ }^{36}$ The discharge capacity of the $\mathrm{MoO}_{3} @ \mathrm{MoO}_{2} / \mathrm{rGO}-500$ heterostructure is $\sim 1340.0 \mathrm{mAh} \mathrm{g}^{-1}$, much higher than those for the bare $\mathrm{MoO}_{3} / \mathrm{rGO}-400$ and $\mathrm{MoO}_{2} / \mathrm{rGO}-600$ electrodes, and the $\mathrm{MoO}_{3} @ \mathrm{MoO}_{2}-500$ without rGO. Figure $2 b$ exhibits the rate performances of all the samples at different current densities. The reversible capacity of the $\mathrm{MoO}_{3} / \mathrm{rGO}-400$ electrode is severely decreased from 734.9 to 110.1 $\mathrm{mAh} \mathrm{g}^{-1}$ when the current density increases from $100 \mathrm{~mA} \mathrm{~g}^{-1}$ to $10 \mathrm{~A} \mathrm{~g}^{-1}(15.0 \%$ capacity retention), suggesting seriously limited $\mathrm{Li}^{+}$diffusion kinetics in $\mathrm{MoO}_{3}$ at high current density. ${ }^{16}$ In contrast, the capacity of the $\mathrm{MoO}_{3} @ \mathrm{MoO}_{2} / \mathrm{rGO}-500$ electrode decreased from 1312.6 to $795.8 \mathrm{mAh} \mathrm{g}^{-1}$ as the current density increased from $100 \mathrm{~mA} \mathrm{~g}^{-1}$ to $10 \mathrm{~A} \mathrm{~g}^{-1}$ (60.6\% capacity retention). As the current returned to $100 \mathrm{~mA} \mathrm{~g}^{-1}$, the capacity of 1187.4 $\mathrm{mAh} \mathrm{g}^{-1}$ was still recovered. The excellent rate performance of the $\mathrm{MoO}_{3} @ \mathrm{MoO}_{2} / \mathrm{rGO}-500$ electrode indicates its high $\mathrm{Li}^{+}$diffusion coefficient, which was further confirmed by collecting CV curves at various scan rates from 0.5 to $10 \mathrm{mV} \mathrm{s}^{-1}$ (Figure S11a-c). Compared with $\mathrm{MoO}_{3} / \mathrm{rGO}-400$ and $\mathrm{MoO}_{2} / \mathrm{rGO}-600$, the shape of the CV curves of $\mathrm{MoO}_{3} @ \mathrm{MoO}_{2} / \mathrm{rGO}-$ 500 is well maintained, with a slight migration of the cathodic and anodic peaks at high scan rates, which implies a small amount of polarization. ${ }^{37}$ The diffusion coefficient of $\mathrm{Li}^{+}$ions as they move in and out of the different electrodes was further estimated based on the following equation: $i_{p}=2.686 \times 10^{5} n^{3 / 2} A D^{1 / 2} c v^{1 / 2}$. (In which $i_{p}, n, D, A, c$, and $v$ stand for the peak current, number of electrons, diffusion coefficient, surface area of the electrode, concentration 
of $\mathrm{Li}^{+}$, and voltage scanning rate, respectively). Apparently, the $i_{p}$ exhibits a linear relationship with $v^{1 / 2}$, in which the slope is proportional to the diffusion coefficient (Figure S11d). ${ }^{38}$ Thus, the diffusion coefficient for $\mathrm{MoO}_{3} / \mathrm{rGO}-400$ is relatively low. Compared with $\mathrm{MoO}_{2} / \mathrm{rGO}-600, \mathrm{MoO}_{3} @ \mathrm{MoO}_{2} / \mathrm{rGO}-500$ shows a higher diffusion coefficient, suggesting a good high-rate capability, possibly due to the importation of $\mathrm{MoO}_{2}$ phase and the interfacial effects of the heterostructure. ${ }^{39}$

The cycling performances of the different electrodes at $2 \mathrm{~A} \mathrm{~g}^{-1}$ were measured (Figure $2 \mathrm{c}$ and Figure S12). The $\mathrm{MoO}_{3} @ \mathrm{MoO}_{2} / \mathrm{rGO}$ and $\mathrm{MoO}_{2} / \mathrm{rGO}$ electrodes show good cycling performance, with the capacity increasing in the initial few tens of cycles, and they maintain a constant capacity during the following cycles. The capacity of $\mathrm{MoO}_{3} / \mathrm{rGO}-400$ fades drastically after 30 cycles, however, and only $207.7 \mathrm{mAh} \mathrm{g}^{-1}$ of capacity is maintained after 200 cycles, which should possibly be ascribed to the pulverization issue. In the XRD pattern collected after 200 cycles (Figure S13), the $\mathrm{MoO}_{3} / \mathrm{rGO}-400$ pattern displays broad and weak peaks, which cannot be assigned to a specific crystalline phase of $\mathrm{MoO}_{x}$ or $\mathrm{Li}_{x} \mathrm{MoO}_{3}{ }^{9}$ In particular, one of the dominant peaks at $\sim 37.2^{\circ}$ has shifted from $38.9^{\circ}$ in the original XRD pattern of $\alpha-\mathrm{MoO}_{3}$ due to the volume expansion. The broad peak indicates that $\mathrm{MoO}_{3} / \mathrm{rGO}$ 400 is incompletely amorphous, although the structure is disordered. ${ }^{16}$ Although the $\mathrm{MoO}_{2}$ peak of the $\mathrm{MoO}_{3} @ \mathrm{MoO}_{2} / \mathrm{rGO}-500$ electrode shows a slight shift to the left, $\mathrm{MoO}_{2}$ still maintains its monoclinic structure even after 200 cycles, and a similar Mo 3d core level XPS spectrum with $3 \mathrm{~d}^{4+}$ and $3 \mathrm{~d}^{6+}$ still can be observed (Figure S14), suggesting high reversibility and structural stability for $\mathrm{MoO}_{2}$. The core-shell structure with its $\mathrm{MoO}_{2}$ shell will help to maintain the structural stability of the composite material, thus improving the cycling performance of the electrode. The $\mathrm{MoO}_{3} @ \mathrm{MoO}_{2} / \mathrm{rGO}-500$ electrode was subjected to prolonged cycling at $5 \mathrm{~A} \mathrm{~g}^{-1}$ (Figure 2d), and it delivered a high reversible capacity of 1208.9 $\mathrm{mAh}^{-1}$ even after 2000 cycles, with a coulombic efficiency of $99.99 \%$, demonstrating 
fascinating high-rate cycling stability, which is very promising compared to the Mo-based anode materials reported so far, including $\mathrm{MoO}_{3-x},{ }^{27} \mathrm{MoO}_{3-x} /$ carbon nanotube (CNT), ${ }^{17}$ $\mathrm{MoO}_{3} @ \mathrm{TiO}_{2},{ }^{16} \mathrm{MoO}_{2} / \mathrm{C}$, and $\mathrm{MoO}_{2} @ \mathrm{rGO},{ }^{20,40}$ as presented in Figure 2e.

In order to deeply understand the electrical conductivity and interfacial effects produced by the creation of heterostructures and the in-situ importation of $\mathrm{MoO}_{2}$, which may be responsible for the enhanced performance of the $\mathrm{MoO}_{3} @ \mathrm{MoO}_{2} / \mathrm{rGO}-500$ electrode, density functional theory (DFT) calculations were carried out to compare $\alpha-\mathrm{MoO}_{3}(\mathrm{Pbnm}, a=3.963$, $b=13.855, c=3.696 \AA$, as shown in Figure 3a) and $\mathrm{MoO}_{2}(\mathrm{P} 21 / \mathrm{c}, a=5.610, b=4.857, c=$ $5.626 \AA$, as shown in Figure 3c), and explore the influence of their interface. Figure 3e reveals the densities of states (DOS) of orthorhombic $\alpha-\mathrm{MoO}_{3}$ and monoclinic $\mathrm{MoO}_{2}$. The results shows that the region near the Fermi level of $\mathrm{MoO}_{2}$ is mainly composed of Mo $3 \mathrm{~d}$ orbitals, demonstrating a metallic character. ${ }^{29}$ Whereas, the highest occupied states of $\alpha$ $\mathrm{MoO}_{3}$ are mostly composed of $\mathrm{O} 2 \mathrm{p}$ orbitals, and the Mo $3 \mathrm{~d}$ orbitals of $\alpha-\mathrm{MoO}_{3}$ are not continuous at the Fermi level (with an obvious band gap for $\alpha-\mathrm{MoO}_{3}$, indicating its semiconducting nature). ${ }^{26}$ The electron density differences in both materials were also plotted, as shown in Figure $3 \mathrm{~b}$ and $3 \mathrm{~d}$, and it is clear that the valence electrons of Mo atoms are transferred to the $\mathrm{O}$ atoms in both materials. An obvious charge transfer in $\alpha-\mathrm{MoO}_{3}$ is observed between $\mathrm{O}$ and Mo atoms, reflecting the strong bonding between them, which endows the polar Mo-O bond with high stability. ${ }^{34}$ In contrast, the abundant nonpolar Mo-Mo metallic bonds in $\mathrm{MoO}_{2}$ enhance the conductivity. According to the above calculations, the partial transformation of $\mathrm{MoO}_{3}$ to form $\mathrm{MoO}_{3} @ \mathrm{MoO}_{2}$ heterostructures will effectively improve the electrical conductivity of the composite.

According to the solid-state reaction kinetics, $\alpha-\mathrm{MoO}_{3}$ is transformed to $\mathrm{MoO}_{2}$ phase along the [010] direction. This reduction process causes the collapse of the successive (010) planes of $\mathrm{MoO}_{3} .{ }^{31}$ The $<100>$ rows in $\mathrm{MoO}_{2}$, during this transformation, constituted by strongly 
linked elements (edge-sharing $\mathrm{MoO}_{6}$ octahedra), are found to be arranged in some directions that are perpendicular or very oblique with respect to the initial (010) surface of $\mathrm{MoO}_{3}{ }^{41}$ In this phase transformation process, the loss of $\mathrm{O}_{(3)}$ lattice oxygen at the (010) facet of $\mathrm{MoO}_{3}$ and the re-organization of lattice oxygen with increasing temperature generate the $n-p$ heterojunctions of $\mathrm{MoO}_{3} @ \mathrm{MoO}_{2}$ with abundant oxygen vacancies at the interface of $\mathrm{MoO}_{3}$ and $\mathrm{MoO}_{2}$ (Figure 3f), thereby providing more active sites for redox reactions, which make a greater contribution to the capacity of the electrode. ${ }^{37,42-44}$ DFT calculations were also performed to provide deeper insight into the interfacial effects on the electrochemical performance of the $\mathrm{MoO}_{3} @ \mathrm{MoO}_{2} / \mathrm{rGO}-500$ electrode (Figure 3g and Figure S15). Similar interface effects have been reported, which demonstrate that the mixed-phase interface not only offers abundant active sites for Li storage but also promotes the reaction kinetics by reducing the resistance. ${ }^{14-15}$ In our case, the oxygen vacancies formed at the interface of $\mathrm{MoO}_{3}$ and $\mathrm{MoO}_{2}$ modify the charge distribution, leading to an unbalanced charge distribution and an interfacial electric field (visualized by the electron density difference map in Figure 3h), which results in a local in-built driving force. ${ }^{24}$ These effects promote electron transport/ion diffusion at the interface, which synergistically leads to the high diffusion coefficient of $\mathrm{Li}^{+}$and high-rate performance of the $\mathrm{MoO}_{3} @ \mathrm{MoO}_{2} / \mathrm{rGO}-500$ electrode.

To fully understand the phase evolution during the charge/discharge process, in-operando synchrotron XRPD of the $\mathrm{MoO}_{3} @ \mathrm{MoO}_{2} / \mathrm{rGO}-500$ electrode was carried out (Figure 4a). Due to its possible preferred orientation, weak peak intensity, and the effects of the electrolyte and separator, the peaks of $\mathrm{MoO}_{3}$ cannot be discerned explicitly (Figure S16a). During the discharge process, the (011) and (022) peaks of $\mathrm{MoO}_{2}$ consecutively shift to lower angles, indicating the increase in the lattice parameter due to the intercalation of $\mathrm{Li}^{+}{ }^{18}$ Then, both peaks are gradually converted into the (011) and (220) peaks of monoclinic $\mathrm{Li}_{0.98} \mathrm{MoO}_{2}$ when the potential reaches $\sim 1.0 \mathrm{~V}$, which is more distinct in the contour maps (Figure $4 \mathrm{~b}$ ). 
Simultaneously, several new diffraction peaks located at $15.5^{\circ}$ and $21.7^{\circ}$ appear, corresponding to the $(\overline{0} 02)$ and $(022)$ crystal planes of $\mathrm{Li}_{0.98} \mathrm{MoO}_{2}$ (Figure $\left.\mathrm{S} 17\right)$, which is consistent with the reaction mechanisms of $\mathrm{MoO}_{2}$ (Figure 3a). ${ }^{30}$ Importantly, a new diffraction peak at $17.9^{\circ}$ is observed, which is ascribed to the (110) planes of Mo (Figure 4c), demonstrating a conversion reaction process. Remarkably, the (011) and (022) peaks of $\mathrm{MoO}_{2}$ completely re-emerge, while the crystalline phase of $\mathrm{Li}_{0.98} \mathrm{MoO}_{2}$ disappears during the charge process, indicating that the crystallinity of the $\mathrm{MoO}_{2}$ phase is well maintained after cycling. The high reversibility of the $\mathrm{MoO}_{2}$ coating phase has benefits for the high-rate cycling stability of the $\mathrm{MoO}_{3} @ \mathrm{MoO}_{2}$ heterostructures.

\section{CONCLUSION}

In summary, heterostructure manipulation was realized by an in-situ localized phase transformation route to synthesize the quasi-core-shell $\mathrm{MoO}_{3} @ \mathrm{MoO}_{2}$ heterostructures anchored on rGO nanosheets. It was demonstrated that the outer $\mathrm{MoO}_{2}$ phase improves the electrochemical performance due to the following reasons: a) the in-situ phase transformation at the boundary and surface not only improves the electronic conductivity of the $\mathrm{MoO}_{3} @ \mathrm{MoO}_{2}$ heterostructures, but also shortens the $\mathrm{Li}^{+}$ion diffusion distance and electron transport in the inner $\mathrm{MoO}_{3}$; b) a disproportionate charge distribution and lattice defects exist at the interface, which provide the force to boost the charge transfer kinetics on the interface and offer more active sites for $\mathrm{Li}^{+}$ion storage; and c) the quasi-core-shell structure helps to stabilize the structure of the active material. Consequently, the $\mathrm{MoO}_{3} @ \mathrm{MoO}_{2} / \mathrm{rGO}-500$ electrode delivers high reversible capacity $\left(1312.6 \mathrm{mAh} \mathrm{g}^{-1}\right.$ at $\left.100 \mathrm{~mA} \mathrm{~g}^{-1}\right)$ and superior high-rate cycling performance (1208.9 $\mathrm{mAh} \mathrm{g}^{-1}$ after 2000 cycles at $5 \mathrm{~A} \mathrm{~g}^{-1}$ ). It is expected that our work can provide another way to optimize the transition metal oxides with heterostructures via in-situ localized phase transformation for high performance in optoelectronics, high-speed electronics, and other applications. 


\section{MATERIALS AND METHODS}

Materials: $\left(\mathrm{NH}_{4}\right)_{6} \mathrm{Mo}_{7} \mathrm{O}_{24} \cdot 4 \mathrm{H}_{2} \mathrm{O}$ and graphite were purchased from Sigma-Aldrich Chemical Co. All other reagents were analytical grade and used directly without further purification.

Synthesis of $\mathbf{M o O}_{3} @ \mathbf{M o O}_{2} / \mathbf{r G O}$ : The GO was prepared via a modified Hummers method. A colloidal GO solution with the concentration of about $2 \mathrm{mg} \mathrm{mL}^{-1}$ was prepared by ultrasonication (KQ-600KDE, $600 \mathrm{~W}$ ) for $24 \mathrm{~h}$. Subsequently, the colloidal GO solution was centrifuged to remove large GO particles at $5000 \mathrm{rpm}$ for $5 \mathrm{~min}$. $\left(\mathrm{NH}_{4}\right)_{6} \mathrm{Mo}_{7} \mathrm{O}_{24} \cdot 4 \mathrm{H}_{2} \mathrm{O}(2.0 \mathrm{~g})$ was dissolved in distilled water $(20 \mathrm{~mL})$ to prepare a $\left(\mathrm{NH}_{4}\right)_{6} \mathrm{Mo}_{7} \mathrm{O}_{24}$ solution. Subsequently, the $\left(\mathrm{NH}_{4}\right)_{6} \mathrm{Mo}_{7} \mathrm{O}_{24}$ solution was added to $200 \mathrm{~mL}$ GO dispersion quickly under magnetic stirring for approximately $10 \mathrm{~min}$. After drying in a vacuum freeze-drying oven, the solidstate precursor, $\left(\mathrm{NH}_{4}\right)_{6} \mathrm{Mo}_{7} \mathrm{O}_{24} / \mathrm{GO}$, was obtained. After that, a calcination procedure was carried out on the solid-state mixture with a given heating rate of $10{ }^{\circ} \mathrm{C} \mathrm{min}{ }^{-1}$ at target temperature of $400,450,500,550$, and $600{ }^{\circ} \mathrm{C}$ for $2 \mathrm{~h}$ in a tubular furnace (SK-G08123K, $\Phi 100 / 92 \times 1000 \mathrm{~mm}^{2}$, under Ar atmosphere with a flow rate of $100 \mathrm{sccm}$ ). Finally, the black sheet-like products, denoted as $\mathrm{MoO}_{3} / \mathrm{rGO}-400, \quad \mathrm{MoO}_{3} @ \mathrm{MoO}_{2} / \mathrm{rGO}-450$, $\mathrm{MoO}_{3} @ \mathrm{MoO}_{2} / \mathrm{rGO}-500, \mathrm{MoO}_{2} / \mathrm{rGO}-550$, and $\mathrm{MoO}_{2} / \mathrm{rGO}-600$ samples, respectively, were collected.

Materials characterization: The obtained materials were investigated by XRD with $\mathrm{Cu} \mathrm{K} \alpha$ radiation at $1{ }^{\circ} \mathrm{C} \min ^{-1}$. XPS measurements were performed on a VG Multilab 2000 (VG Inc.) photoelectron spectrometer by employing the monochromatic $\mathrm{Al} \mathrm{K} \alpha$ radiation under vacuum at $2 \times 10^{-6} \mathrm{~Pa}$. The morphologies of the as-prepared $\mathrm{MoO}_{3} / \mathrm{rGO}, \mathrm{MoO}_{3} @ \mathrm{MoO}_{2} / \mathrm{rGO}$, and $\mathrm{MoO}_{2} / \mathrm{rGO}$ sheets were observed by SEM (JEOL JSM-7500FA). The details of the crystal structure and energy dispersive spectroscopy (EDS) mapping were further examined by scanning TEM (STEM) (JEOL JEM-ARM200F), which was conducted at $80 \mathrm{kV}$. Atomic force microscopy was conducted via a Veeco DI Nano-scope MultiMode V system. 
Continuous-wave EPR experiments were conducted on a Bruker ELEXSYS E580 spectrometer operating in the X-band $(9.4 \mathrm{GHz})$ mode.

Electrochemical measurements: CR2032 coin-type cells were used to conduct the electrochemical tests, in which the working electrodes were prepared by mixing, Super P, poly(acrylic acid)/sodium carboxymethyl cellulose (1:1), and the obtained materials in a weight ratio of 10:10:80, dried at $80{ }^{\circ} \mathrm{C}$ in vacuum-oven for $12 \mathrm{~h} .1 \mathrm{M} \mathrm{LiPF}_{6}$ in ethylene carbonate/diethyl carbonate/dimethyl carbonate $(1 / 1 / 1 ; \mathrm{v} / \mathrm{v})$ with $5 \mathrm{wt} \%$ fluoroethylene carbonate was employed as the electrolyte. CV data were collected at different scan rates on a VMP-3 electrochemical workstation. The cells were galvanostatically charged-discharged with a voltage window of $0.01-3.0 \mathrm{~V}$ versus $\mathrm{Li} / \mathrm{Li}^{+}$on the Neware battery tester at different current densities

In-operando synchrotron X-ray powder diffraction (XRPD): A synchrotron cell was used for in-operando XRPD measurements of $\mathrm{MoO}_{3} @ \mathrm{MoO}_{2} / \mathrm{rGO}-500$ sample, which is similar to the coin cells used in electrochemical testing. The cell was galvanostatically chargeddischarged in $0.1-3.0 \mathrm{~V}\left(v s . \mathrm{Li}^{+} / \mathrm{Li}\right)$ at $0.18 \mathrm{~mA}\left(\sim 200 \mathrm{~mA} \mathrm{~g}{ }^{-1}\right)$. The XRPD patterns were collected every 3 min using a MYTHEN micro-strip detector during the charge-discharge process. The used wavelength was detected to be $0.6887 \AA$ using a LaB 6 NIST SRM $660 \mathrm{~b}$ (Australian Synchrotron).

Theoretical calculations: The Cambridge Serial Total Energy Package (CASTEP), a firstprinciples plane wave pseudopotential method based on the DFT, was employed to carry on all calculations. In order to achieve a good convergence of the total energy as well as force acting on the atoms, the cut-off energy of the plane wave basis, for all models, was set at 340 eV. Special points sampling integration over the Brillouin zone was used in the MonkhorstPack method with $5 \times 5 \times 5,6 \times 2 \times 7$, and $2 \times 2 \times 1$ special k-point meshes for $\mathrm{MoO}_{2}$ and $\mathrm{MoO}_{3}$ crystal cells, and $\mathrm{MoO}_{3}(010) / \mathrm{MoO}_{2}(100)$ heterointerface models, respectively. 
As experimentally determined, $\mathrm{MoO}_{3}$ exhibits the orthorhombic structure with space group Pbnm. Its unit cell contains four formula units with the lattice constants of $a=3.963, b=$ 13.855, and $c=3.696 \AA$, as shown in Figure S13. As experimentally determined, $\mathrm{MoO}_{2}$ presents the monoclinic structure with space group $\mathrm{P} 21 / \mathrm{c}$, and the unit cell contains two formula units with the lattice constants $a=5.610 \AA, b=4.857 \AA$, and $c=5.626 \AA$, as shown in Figure S2. To simulate the interface of $\mathrm{MoO}_{3}(010) / \mathrm{MoO}_{2}(100)$, an $\alpha-\mathrm{MoO}_{3}(010)(3 \times 3)$ slab with 8 atomic layers was constructed to match with a $\mathrm{MoO}_{2}(100)(2 \times 2)$ slab with 6 atomic layers by keeping the thickness of the layers constant, as shown in Figure S14. A vacuum thickness of $20 \AA$ was set to avoid interaction between neighboring slabs. The average lattice constants of the constructed $\mathrm{MoO}_{3}(010) / \mathrm{MoO}_{2}(100)$ heterointerface were $a=$ $10.4012 \AA$ and $b=11.5680 \AA$.

\section{ACKNOWLEDGEMENTS}

This research has been carried out with the support of a Matching Scholarship from the University of Wollongong (J.H.), and the Australian Research Council (ARC) through a Discovery project (DP170102406) and a Future Fellowship project (FT150100109). The Electron Microscopy Centre (University of Wollongong) is owed thanks for the characterizations of SEM and TEM, as well as Prof. Ping Peng (Hunan University) due to his support of the software for DFT calculations, and Dr. Tania Silver for critical reading of the manuscript and valuable remarks.

\section{ASSOCIATED CONTENT}

Supporting Information. The Supporting Information is available free of charge on the ACS Publications website at http://pubs.acs.org. 


\section{REFERENCES}

1. Hong, X.; Kim, J.; Shi, S.-F.; Zhang, Y.; Jin, C.; Sun, Y.; Tongay, S.; Wu, J.; Zhang, Y.; Wang, F., Ultrafast Charge Transfer in Atomically Thin $\mathrm{MoS}_{2} / \mathrm{WS}_{2}$ Heterostructures. Nat. Nanotechnol. 2014, 9, 682.

2. Chen, C.; Xie, X.; Anasori, B.; Sarycheva, A.; Makaryan, T.; Zhao, M.; Urbankowski, P.; Miao, L.; Jiang, J.; Gogotsi, Y., $\mathrm{MoS}_{2}$-on-Mxene Heterostructures as Highly Reversible Anode Materials for Lithium-Ion Batteries. Angew. Chem. Int. Ed. 2018, 57, 1846-1850.

3. Pentcheva, R.; Pickett, W. E., Charge Localization or Itineracy at $\mathrm{LaAlO}_{3} \mathrm{SrTiO}_{3}$ Interfaces: Hole Polarons, Oxygen Vacancies, and Mobile Electrons. Phys. Rev. B. 2006, 74, 035112.

4. Gautam, U. K.; Fang, X.; Bando, Y.; Zhan, J.; Golberg, D., Synthesis, Structure, and Multiply Enhanced Field-Emission Properties of Branched ZnS Nanotube-in Nanowire Core-Shell Heterostructures. ACS Nano 2008, 2, 1015-1021.

5. Sata, N.; Eberman, K.; Eberl, K.; Maier, J., Mesoscopic Fast Ion Conduction in Nanometre-Scale Planar Heterostructures. Nature 2000, 408, 946.

6. Fang, Y.; Lv, Y.; Gong, F.; Elzatahry, A. A.; Zheng, G.; Zhao, D., Synthesis of 2D-

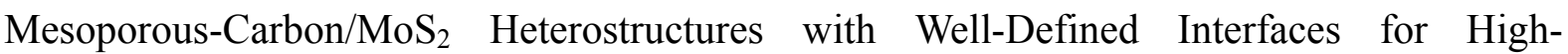
Performance Lithium-Ion Batteries. Adv. Mater. 2016, 28, 9385-9390.

7. Liu, Y. T.; Zhang, P.; Sun, N.; Anasori, B.; Zhu, Q. Z.; Liu, H.; Gogotsi, Y.; Xu, B., Self-Assembly of Transition Metal Oxide Nanostructures on Mxene Nanosheets for Fast and Stable Lithium Storage. Adv. Mater. 2018, 30, 1707334.

8. $\quad$ Mai, L. Q.; Hu, B.; Chen, W.; Qi, Y.; Lao, C.; Yang, R.; Dai, Y.; Wang, Z. L., Lithiated $\mathrm{MoO}_{3}$ Nanobelts with Greatly Improved Performance for Lithium Batteries. Adv. Mater. 2007, 19, 3712-3716.

9. Lee, S. H.; Kim, Y. H.; Deshpande, R.; Parilla, P. A.; Whitney, E.; Gillaspie, D. T.; 
Jones, K. M.; Mahan, A. H.; Zhang, S.; Dillon, A. C., Reversible Lithium-Ion Insertion in Molybdenum Oxide Nanoparticles. Adv. Mater. 2008, 20, 3627-3632.

10. Choi, S. H.; Kang, Y. C., Crumpled Graphene-Molybdenum Oxide Composite Powders: Preparation and Application in Lithium-Ion Batteries. ChemSusChem 2014, 7, 523528.

11. Zhu, C. B.; Usiskin, R. E.; Yu, Y.; Maier, J., The Nanoscale Circuitry of Battery Electrodes. Science 2017, 358, 2808.

12. Wang, S.; Zhang, H. J.; Zhang, D.; Ma, Y.; Bi, X. F.; Yang, S. B., Vertically Oriented Growth of $\mathrm{MoO}_{3}$ Nanosheets on Graphene for Superior Lithium Storage. J. Mater. Chem. A. 2018, 6, 672-679.

13. Cheng, X. P.; Li, Y. H.; Sang, L. J.; Ma, J. Y.; Shi, H. F.; Liu, X. Q.; Lu, J. X.; Zhang, Y. F., Boosting the Electrochemical Performance of $\mathrm{MoO}_{3}$ Anode for Long-Life Lithium Ion Batteries: Dominated by an Ultrathin $\mathrm{TiO}_{2}$ Passivation Layer. Electrochim. Acta 2018, 269, 241-249.

14. Zheng, Y.; Zhou, T. F.; Zhang, C. F.; Mao, J. F.; Liu, H. K.; Guo, Z. P., Boosted Charge Transfer in $\mathrm{SnS} / \mathrm{SnO}_{2}$ Heterostructures: Toward High Rate Capability for Sodium-Ion Batteries. Angew. Chem. Int. Ed. 2016, 55, 3408-3413.

15. Kim, H. S.; Cook, J. B.; Lin, H.; Ko, J. S.; Tolbert, S. H.; Ozolins, V.; Dunn, B., Oxygen Vacancies Enhance Pseudocapacitive Charge Storage Properties of $\mathrm{MoO}_{3-\mathrm{x}}$. Nat. Mater. 2017, 16, 454.

16. Wang, C.; Wu, L. X.; Wang, H.; Zuo, W. H.; Li, Y. Y.; Liu, J. P., Fabrication and Shell Optimization of Synergistic $\mathrm{TiO}_{2}-\mathrm{MoO}_{3}$ Core-Shell Nanowire Array Anode for High Energy and Power Density Lithium-Ion Batteries. Adv. Funct. Mater. 2015, 25, 3524-3533.

17. Ni, J. F.; Wang, G. B.; Yang, J.; Gao, D. L.; Chen, J. T.; Gao, L. J.; Li, Y., Carbon Nanotube-Wired and Oxygen-Deficient $\mathrm{MoO}_{3}$ Nanobelts with Enhanced Lithium-Storage 
Capability. J. Power Sources 2014, 247, 90-94.

18. Sun, Y. M.; Hu, X. L.; Luo, W.; Huang, Y. H., Self-Assembled Hierarchical $\mathrm{MoO}_{2} /$ Graphene Nanoarchitectures and Their Application as a High-Performance Anode Material for Lithium-Ion Batteries. ACS Nano 2011, 5, 7100-7107.

19. Balendhran, S.; Deng, J. K.; Ou, J. Z.; Walia, S.; Scott, J.; Tang, J. S.; Wang, K. L.; Field, M. R.; Russo, S.; Zhuiykov, S.; Strano, M. S.; Medhekar, N.; Sriram, S.; Bhaskaran, M.; Kalantar-Zadeh, K., Enhanced Charge Carrier Mobility in Two-Dimensional High Dielectric Molybdenum Oxide. Adv. Mater. 2013, 25, 109-114.

20. Wang, P. X.; Zhang, Y.; Yin, Y. Y.; Fan, L. S.; Zhang, N. Q.; Sun, K. N., Anchoring Hollow $\mathrm{MoO}_{2}$ Spheres on Graphene for Superior Lithium Storage. Chem. Eng. J. 2018, 334, $257-263$

21. Liu, Y. T.; Zhang, P.; Sun, N.; Anasori, B.; Zhu, Q. Z.; Liu, H.; Gogotsi, Y.; Xu, B., Self-Assembly of Transition Metal Oxide Nanostructures on Mxene Nanosheets for Fast and Stable Lithium Storage. Adv. Mater. 2018, 30,1707334.

22. Zhou, T. F.; Zheng, Y.; Gao, H.; Min, S. D.; Li, S.; Liu, H. K.; Guo, Z. P., Surface Engineering and Design Strategy for Surface-Amorphized $\mathrm{TiO}_{2} @$ Graphene Hybrids for High Power Li-Ion Battery Electrodes. Adv. Sci. 2015, 2, 1500027.

23. Smith, A. M.; Lane, L. A.; Nie, S. M., Mapping the Spatial Distribution of Charge Carriers in Quantum-Confined Heterostructures. Nat. Commun. 2014, 5, 4506.

24. Basletic, M.; Maurice, J. L.; Carretero, C.; Herranz, G.; Copie, O.; Bibes, M.; Jacquet, E.; Bouzehouane, K.; Fusil, S.; Barthelemy, A., Mapping the Spatial Distribution of Charge Carriers in $\mathrm{LaAlO}_{3} / \mathrm{SrTiO}_{3}$ Heterostructures. Nat. Mater. 2008, 7, 621-625.

25. Ni, J. F.; Zhao, Y.; Li, L.; Mai, L. Q., Ultrathin $\mathrm{MoO}_{2}$ Nanosheets for Superior Lithium Storage. Nano Energy 2015, 11, 129-135.

26. Shon, J. K.; Lee, H. S.; Park, G. O.; Yoon, J.; Park, E.; Park, G. S.; Kong, S. S.; Jin, 
M.; Choi, J. M.; Chang, H.; Doo, S.; Kim, J. M.; Yoon, W. S.; Pak, C.; Kim, H.; Stucky, G.

D., Discovery of Abnormal Lithium-Storage Sites in Molybdenum Dioxide Electrodes. Nat. Commun. 2016, 7, 11049.

27. Zhang, G.; Xiong, T.; Yan, M.; He, L.; Liao, X.; He, C.; Yin, C.; Zhang, H.; Mai, L., $\alpha-\mathrm{MoO}_{3-\mathrm{x}}$ by Plasma Etching with Improved Capacity and Stabilized Structure for Lithium Storage. Nano Energy 2018, 49, 555-563.

28. Wang, W.; Qin, J.; Yin, Z.; Cao, M., Achieving Fully Reversible Conversion in $\mathrm{MoO}_{3}$ for Lithium Ion Batteries by Rational Introduction of $\mathrm{CoMoO}_{4}$. ACS Nano 2016, 10, 1010610116.

29. Scanlon, D. O.; Watson, G. W.; Payne, D. J.; Atkinson, G. R.; Egdell, R. G.; Law, D. S. L., Theoretical and Experimental Study of the Electronic Structures of $\mathrm{MoO}_{3}$ and $\mathrm{MoO}_{2}$. J. Phys. Chem. C 2010, 114, 4636-4645.

30. Ren, Y.; Armstrong, A. R.; Jiao, F.; Bruce, P. G., Influence of Size on the Rate of Mesoporous Electrodes for Lithium Batteries. J. Am. Chem. Soc. 2010, 132, 996-1004.

31. Ressler, T.; Wienold, J.; Jentoft, R. E.; Neisius, T., Bulk Structural Investigation of the Reduction of $\mathrm{MoO}_{3}$ with Propene and the Oxidation of $\mathrm{MoO}_{2}$ with Oxygen. J. Catal. 2002, 210, 67-83.

32. Liu, Y. W.; Zhou, T. F.; Zheng, Y.; He, Z. H.; Xiao, C.; Pang, W. K.; Tong, W.; Zou, Y. M.; Pan, B. C.; Guo, Z. P.; Xie, Y., Local Electric Field Facilitates High-Performance Li-Ion Batteries. ACS Nano 2017, 11, 8519-8526.

33. Lalik, E., Kinetic Analysis of Reduction of $\mathrm{MoO}_{3}$ to $\mathrm{MoO}_{2}$. Catal. Today 2011, 169, $85-92$.

34. Janotti, A.; Van de Walle, C. G., Oxygen Vacancies in ZnO. Appl. Phys. Lett. 2005, $87,122102$.

35. Wang, P. F.; Yao, H. R.; Liu, X. Y.; Yin, Y. X.; Zhang, J. N.; Wen, Y. R.; Yu, X. Q.; 
Gu, L.; Guo, Y. G., Na ${ }^{+} /$Vacancy Disordering Promises High-Rate Na-Ion Batteries. Sci. Adv. 2018, 4, 6018.

36. Zhang, P.; Zou, L.; Hu, H. X.; Wang, M. R.; Fang, J.; Lai, Y. Q.; Li, J., 3d Hierarchical Carbon Microflowers Decorated with $\mathrm{MoO}_{2}$ Nanoparticles for Lithium Ion Batteries. Electrochim. Acta 2017, 250, 219-227.

37. Shin, J. Y.; Joo, J. H.; Samuelis, D.; Maier, J., Oxygen-Deficient $\mathrm{TiO}_{2}$-Delta Nanoparticles Via Hydrogen Reduction for High Rate Capability Lithium Batteries. Chem. Mater. 2012, 24, 543-551.

38. Gao, H.; Zhou, T.; Zheng, Y.; Zhang, Q.; Liu, Y.; Chen, J.; Liu, H.; Guo, Z., Cos Quantum Dot Nanoclusters for High Energy Potassium Ion Batteries. Adv. Funct. Mater. 2017, 27, 1702634.

39. Zheng, Y.; Zhou, T. F.; Zhao, X. D.; Pang, W. K.; Gao, H.; Li, S.; Zhou, Z.; Liu, H. K.; Guo, Z. P., Atomic Interface Engineering and Electric-Field Effect in Ultrathin $\mathrm{Bi}_{2} \mathrm{MoO}_{6}$ Nanosheets for Superior Lithium Ion Storage. Adv. Mater. 2017, 29, 1700396.

40. Tian, W.; Hu, H.; Wang, Y. X.; Li, P.; Liu, J. Y.; Liu, J. L.; Wang, X. B.; Xu, X. D.; Li, Z. T.; Zhao, Q. S.; Ning, H.; Wu, W. T.; Wu, M. B., Metal-Organic Frameworks Mediated Synthesis of One-Dimensional Molybdenum-Based/Carbon Composites for Enhanced Lithium Storage. ACS Nano 2018, 12, 1990-2000.

41. Bertrand, O.; Dufour, L. C., X-Ray and Electron-Microscopy Investigation of the Topotactic Transformation of $\mathrm{MoO}_{3}$ into $\mathrm{MoO}_{2}$. Phys. Status Solidi A 1980, 60, 507-519.

42. Xu, Y.; Zhou, M.; Wang, X.; Wang, C. L.; Liang, L. Y.; Grote, F. B.; Wu, M. H.; Mi, Y.; Lei, Y., Enhancement of Sodium Ion Battery Performance Enabled by Oxygen Vacancies. Angew. Chem. Int. Ed. 2015, 54, 8768-8771.

43. Greiner, M. T.; Lu, Z.H., Thin-film Metal Oxides in Organic Semiconductor Devices: Their Electronic Structures, Work Functions and Interfaces. NPG Asia Mater. 2013, 5, 55. 
44. Ratna Phani, A.; Manorama, S.; Rao, V., Effect of Additives on the Response of Sensors Utilizing Semiconducting Oxide on Carbon Monoxide Sensitivity. Appl. Phys. Lett. 1995, 66, 3489-3491. 

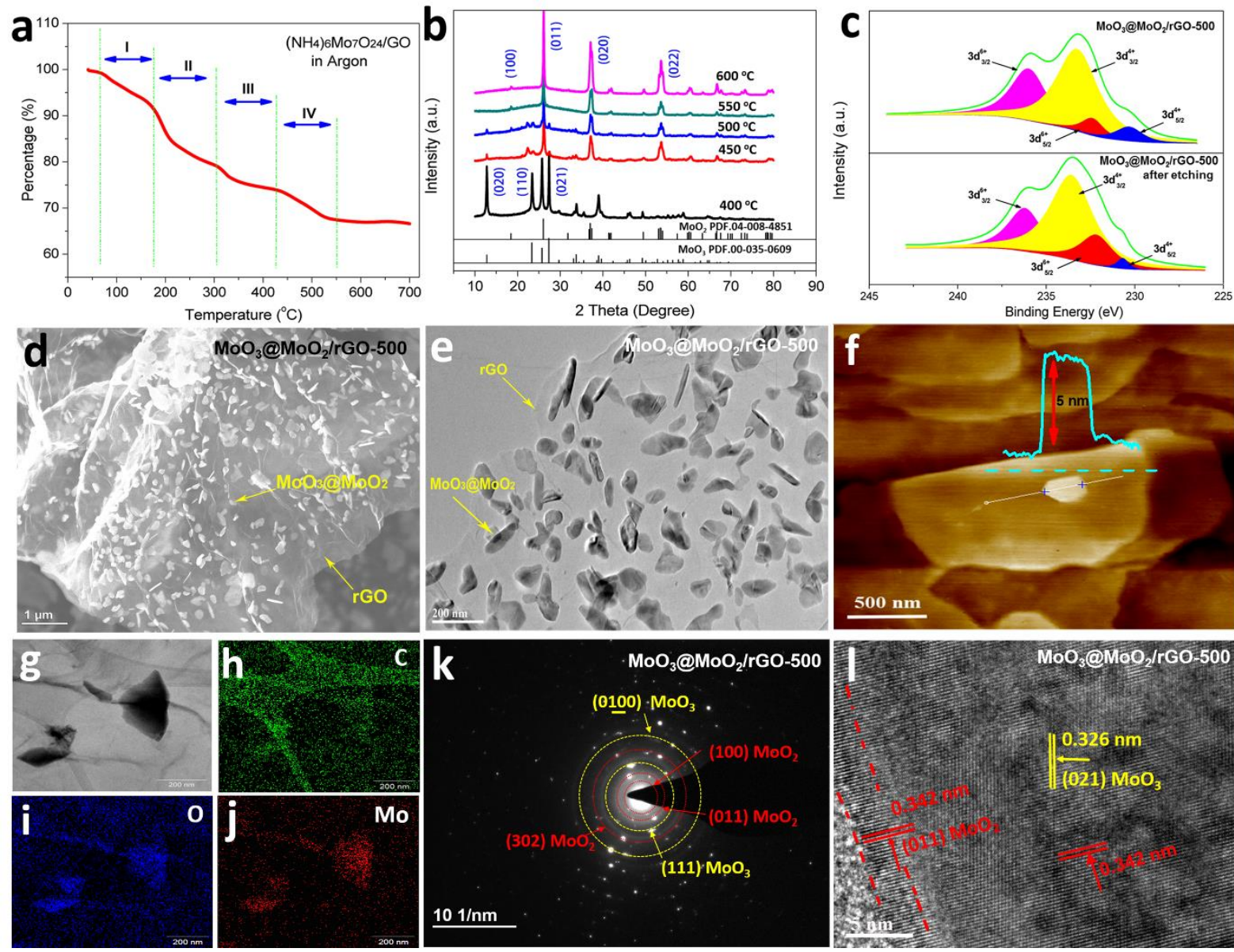

Figure 1. Crystal structure, compositional characterization, and morphology of $\mathrm{MoO}_{3} @$

$\mathrm{MoO}_{2} /$ rGO sheets. (a) TGA curve of precursor, $\left(\mathrm{NH}_{4}\right)_{6} \mathrm{Mo}_{7} \mathrm{O}_{24} / \mathrm{GO}$, under calcining from ambient temperature to $700{ }^{\circ} \mathrm{C}$ in argon. (b) XRD patterns of the different samples obtained at various temperatures (from 400 to $600{ }^{\circ} \mathrm{C}$ ). (c) High-resolution XPS spectra of $\mathrm{MoO}_{3} @ \mathrm{MoO}_{2} / \mathrm{rGO}-500$ sample before and after argon plasma etching. (d) SEM image of $\mathrm{MoO}_{3} @ \mathrm{MoO}_{2} / \mathrm{rGO}-500$ nanosheets. (e) TEM image of $\mathrm{MoO}_{3} @ \mathrm{MoO}_{2} / \mathrm{rGO}-500$ nanosheets. (f) Atomic force microscope (AFM) image of $\mathrm{MoO}_{3} @ \mathrm{MoO}_{2} / \mathrm{rGO}-500$ and corresponding height profile. (g-j) Scanning TEM (STEM) image with corresponding energy dispersive spectroscopy (EDS) elemental mappings. (k) The selected area electron diffraction (SAED) pattern of $\mathrm{MoO}_{3} @ \mathrm{MoO}_{2} / \mathrm{rGO}-500$ sample with complex polycrystalline diffraction spots that correspond to the monoclinic $\mathrm{MoO}_{2}$ and $\alpha-\mathrm{MoO}_{3}$ phases. (l) HRTEM image of $\mathrm{MoO}_{3} @ \mathrm{MoO}_{2} / \mathrm{rGO}-500$ sample. Two kinds of lattice spacing can be observed. 

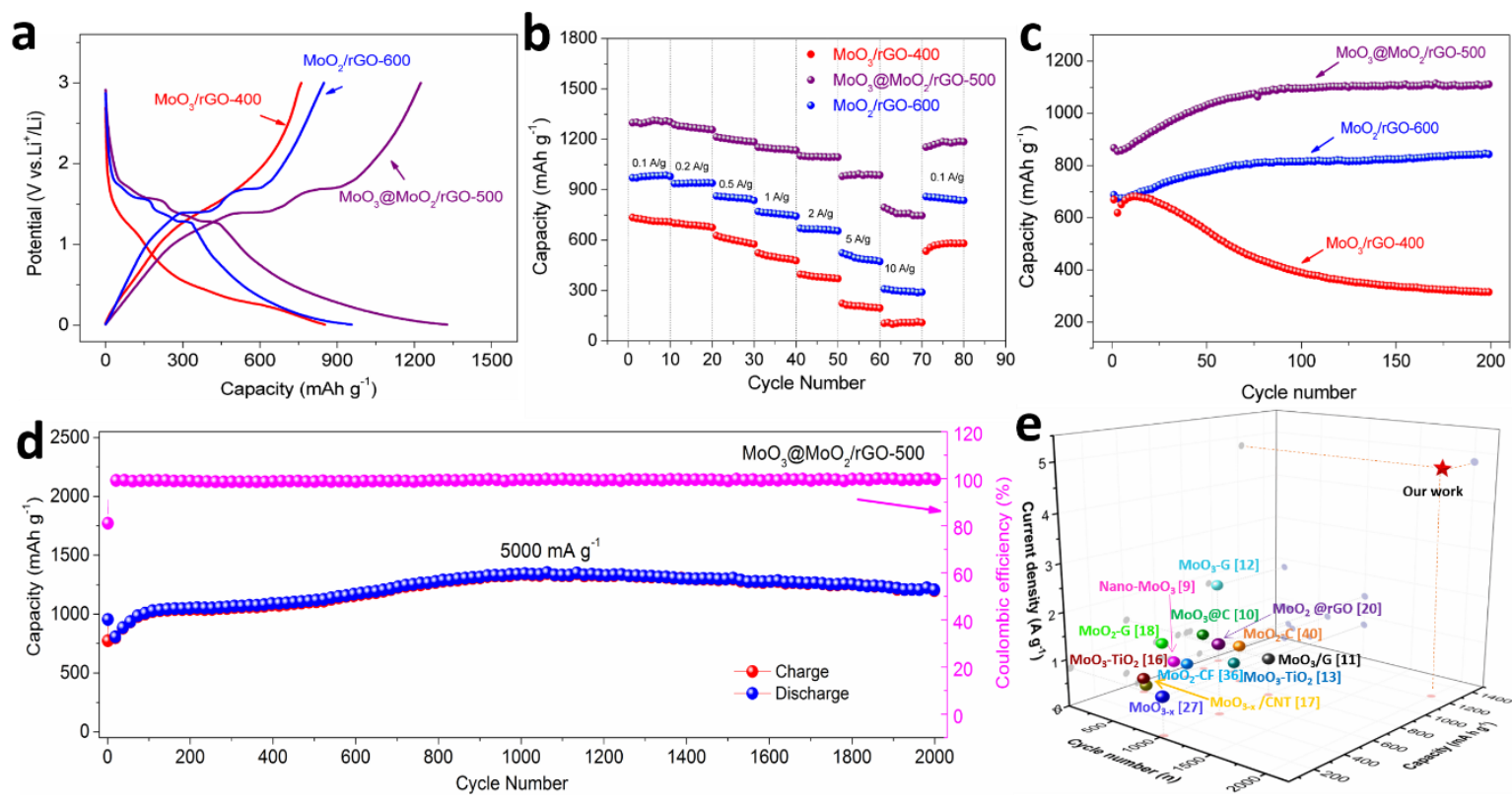

Figure 2. Electrochemical performance of different electrodes. (a) Typical galvanostatic discharge-charge profiles of $\mathrm{MoO}_{3} / \mathrm{rGO}-400, \mathrm{MoO}_{3} @ \mathrm{MoO}_{2} / \mathrm{rGO}-500$, and $\mathrm{MoO}_{2} / \mathrm{rGO}-600$ electrodes at $100 \mathrm{~mA} \mathrm{~g}^{-1}$. (b) Rate performances of $\mathrm{MoO}_{3} / \mathrm{rGO}-400, \mathrm{MoO}_{3} @ \mathrm{MoO}_{2} / \mathrm{rGO}-500$, and $\mathrm{MoO}_{2} / \mathrm{rGO}-600$ electrodes at current densities from $100 \mathrm{~mA} \mathrm{~g}^{-1}$ to $10 \mathrm{~A} \mathrm{~g}^{-1}$. (c) Cycling performances of $\mathrm{MoO}_{3} / \mathrm{rGO}-400, \mathrm{MoO}_{3} @ \mathrm{MoO}_{2} / \mathrm{rGO}-500$, and $\mathrm{MoO}_{2} / \mathrm{rGO}-600$ electrodes at $2 \mathrm{~A} \mathrm{~g}^{-1}$. (d) Long-term high-rate cycling performance of the $\mathrm{MoO}_{3} @ \mathrm{MoO}_{2} / \mathrm{rGO}-500$ electrode and the corresponding coulombic efficiency at $5 \mathrm{~A} \mathrm{~g}^{-1}$. (e) Comparison of the highrate cycling performance of the $\mathrm{MoO}_{3} @ \mathrm{MoO}_{2} / \mathrm{rGO}-500$ electrode with other reported Mobased anodes in LIBs. 

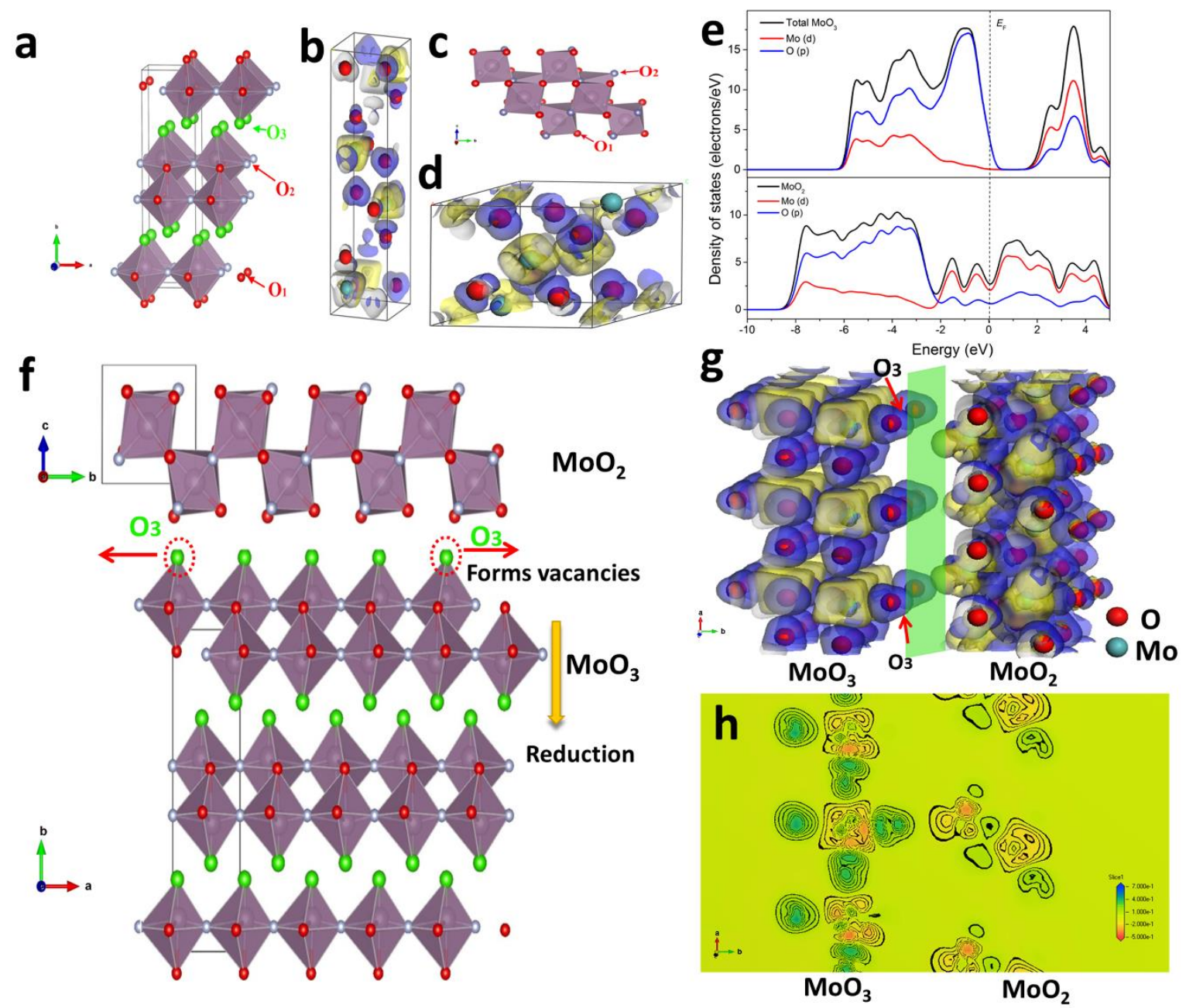

Figure 3. Structural information, in-situ phase transformation, and charge density distribution of $\mathrm{MoO}_{3} @ \mathrm{MoO}_{2}$ heterostructures. (a) The crystal structure of $\alpha-\mathrm{MoO}_{3}$ with a bilayer network of edge-sharing $\mathrm{MoO}_{6}$ octahedra. There are three nonequivalent oxygen atoms: (i) asymmetric oxygens, $\mathrm{O}_{(1)}$, that bridge two Mo centers along the $z$ axis; (ii) three coordinated oxygens, $\mathrm{O}_{(2)}$, that form a symmetrical bridge along the $x$ axis between two Mo centers on the same layer and interact with a sublayer Mo; and (iii) terminal oxygens, $\mathrm{O}_{(3)}$, which are double bonded to only one Mo center that is present in the interlayer region. (b) Electron density differences for orthorhombic $\mathrm{MoO}_{3}$ (c) The structure of monoclinic $\mathrm{MoO}_{2}$. (d) Electron density differences for $\mathrm{MoO}_{2}$. (e) Comparison of densities of states of $\mathrm{MoO}_{3}$ and $\mathrm{MoO}_{2}$. (f) Schematic representation of the in-situ phase transformation to form $\mathrm{MoO}_{3} @ \mathrm{MoO}_{2}$ 
heterostructures. (g) Model for the interface of a $\mathrm{MoO}_{3} @ \mathrm{MoO}_{2}$ heterostructure with oxygen vacancies. (h) Electron density difference map of the interface of a $\mathrm{MoO}_{3} @ \mathrm{MoO}_{2}$ heterostructure. 

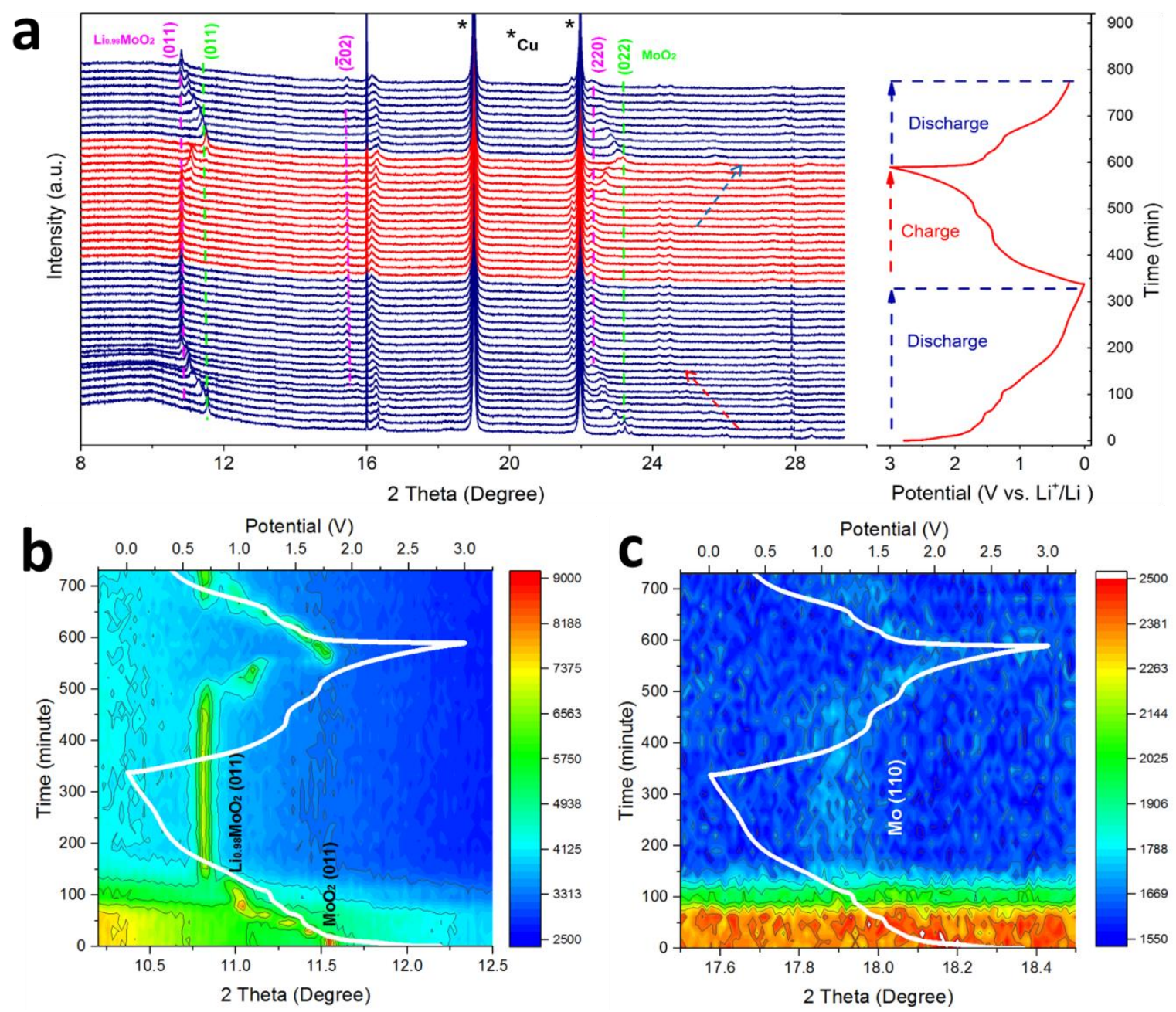

Figure 4. Crystal structural evolution under the $\mathrm{Li}^{+}$(de)intercalation process. (a) Inoperando synchrotron XRPD patterns of the $\mathrm{MoO}_{3} @ \mathrm{MoO}_{2} / \mathrm{rGO}-500$ electrode were collected during the initial discharge-charge process at $200 \mathrm{~mA} \mathrm{~g}^{-1}$. Contour plots of the operando synchrotron XRPD data: (b) $10.0^{\circ}-12.5^{\circ}$, where the (011) peak of $\mathrm{MoO}_{2}$ is converted to the (011) peak of $\mathrm{Li}_{0.98} \mathrm{MoO}_{2}$ during the initial discharge process; (c) $17.5^{\circ}-18.5^{\circ}$, where the peak of Mo can be observed at about $17.9^{\circ}$, demonstrating the partial conversion of $\mathrm{MoO}_{3} @ \mathrm{MoO}_{2}$ heterostructures into Mo in the discharging process. 
Supporting Information

\section{Heterostructure Manipulation via In-Situ Localized Phase Transformation for High- Rate and Highly Durable Lithium Ion Storage}

Junnan $\mathrm{Hao}^{\dagger}$, Jian Zhang ${ }^{\star}$, Guanglin Xia ${ }^{\dagger}$, Yajie Liu ${ }^{\dagger}$, Yang Zheng ${ }^{\dagger}$, Wenchao Zhang ${ }^{\dagger}$, Yongbing Tang ${ }^{*}$, Wei Kong Pang ${ }^{\dagger}$, Zaiping Guo* ${ }^{\dagger}$

${ }^{\dagger}$ Institute for Superconducting \& Electronic Materials, School of Mechanical, Materials and Mechatronics Engineering, University of Wollongong, Wollongong, NSW 2522, Australia

${ }^{\ddagger}$ College of Automotive and Mechanical Engineering, Changsha University of Science and Technology, Changsha 410114, China

${ }^{\S}$ Functional Thin Films Research Center; Shenzhen Institutes of Advanced Technology, Chinese Academy of Sciences, Shenzhen 518055, China

\begin{tabular}{llllll}
\hline & $400{ }^{\circ} \mathrm{C}$ & $500{ }^{\circ} \mathrm{C}$ & $500{ }^{\circ} \mathrm{C}$ etching & $600{ }^{\circ} \mathrm{C}$ & Peak position (eV) \\
$\mathrm{Mo}^{+6}{ }_{5 / 2}$ & $63.26 \%$ & $5.01 \%$ & $16.13 \%$ & $3.62 \%$ & 232.3 \\
$\mathrm{Mo}^{+6}{ }_{3 / 2}$ & $33.74 \%$ & $28.40 \%$ & $23.69 \%$ & $10.01 \%$ & 236.1 \\
$\mathrm{Mo}_{5 / 2}^{+4}$ & 0 & $6.25 \%$ & $2.05 \%$ & $31.16 \%$ & 230.7 \\
$\mathrm{Mo}^{+4}{ }_{3 / 2}$ & 0 & $60.34 \%$ & $58.13 \%$ & $55.21 \%$ & 233.5 \\
\hline
\end{tabular}

Table S1. The positions of the $3 \mathrm{~d} \mathrm{Mo}^{6+}$ and $3 \mathrm{~d} \mathrm{Mo}^{4+}$ peaks in the XPS spectra of Mo $3 \mathrm{~d}$ and their related contents in various samples. 


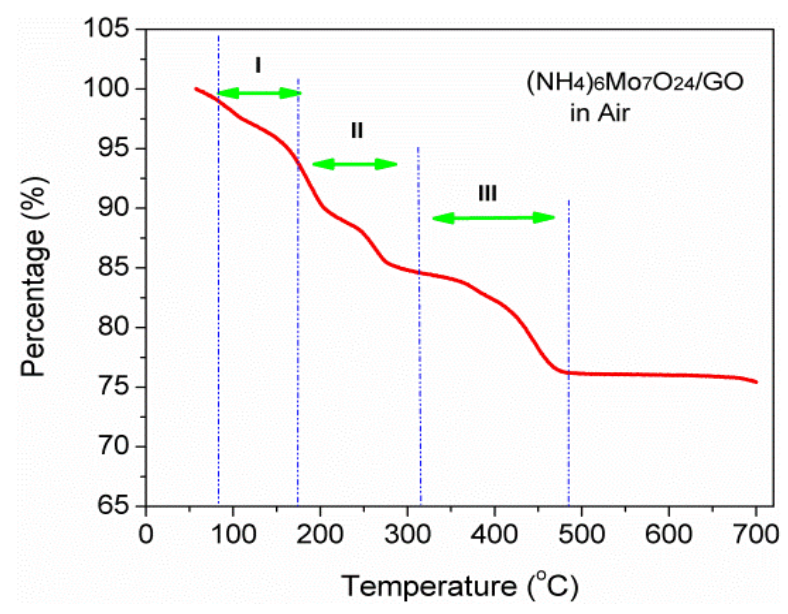

Figure S1. TGA curves of the $\left(\mathrm{NH}_{4}\right)_{6} \mathrm{Mo}_{7} \mathrm{O}_{24} / \mathrm{GO}$ precursor, tested in air flow from ambient temperature to $700{ }^{\circ} \mathrm{C}$. There are three obvious weight loss regions: the first $\left(50-180{ }^{\circ} \mathrm{C}\right)$ and the second regions $\left(180-310^{\circ} \mathrm{C}\right)$ originate from the removal of the remaining interlayer moisture and the decomposition of $\left(\mathrm{NH}_{4}\right)_{6} \mathrm{Mo}_{7} \mathrm{O}_{24}$, respectively. The following loss at approximately $300-420^{\circ} \mathrm{C}$ is due to the oxidative decomposition reaction of GO sheets. As a result, the content of rGO in the composite was found to be $\sim 6.8 \mathrm{wt} \%{ }^{1}$ 

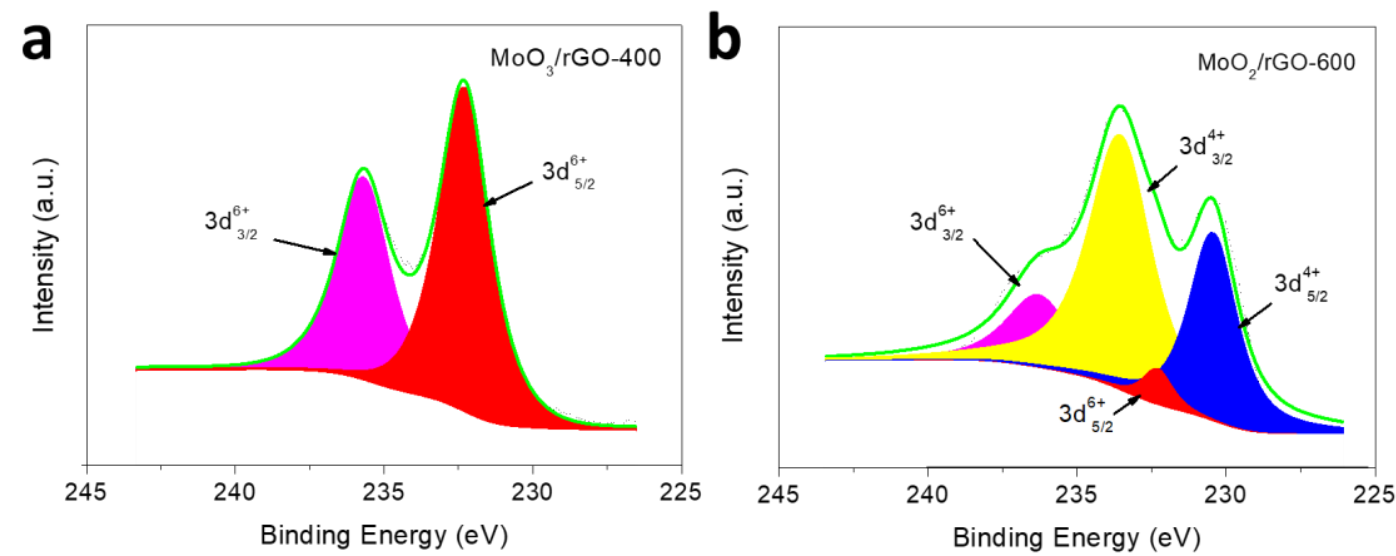

Figure S2. High-resolution XPS spectra of $\mathrm{MoO}_{3} / \mathrm{rGO}-400$ (a) and $\mathrm{MoO}_{2} / \mathrm{rGO}-600$ (b) sheets in the Mo 3d region. 


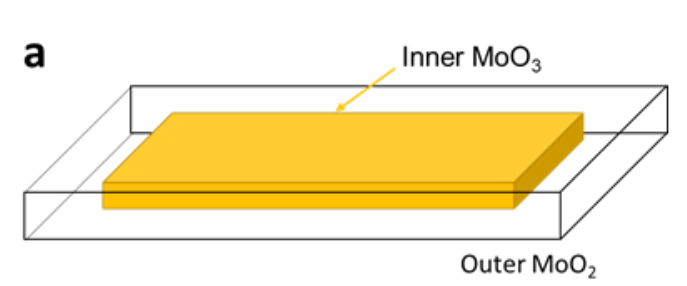

b

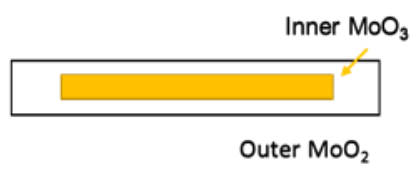

Figure S3. (a) Schematic illustration of $\mathrm{MoO}_{3} @ \mathrm{MoO}_{2}$ heterostructures, (b) lateral view. 

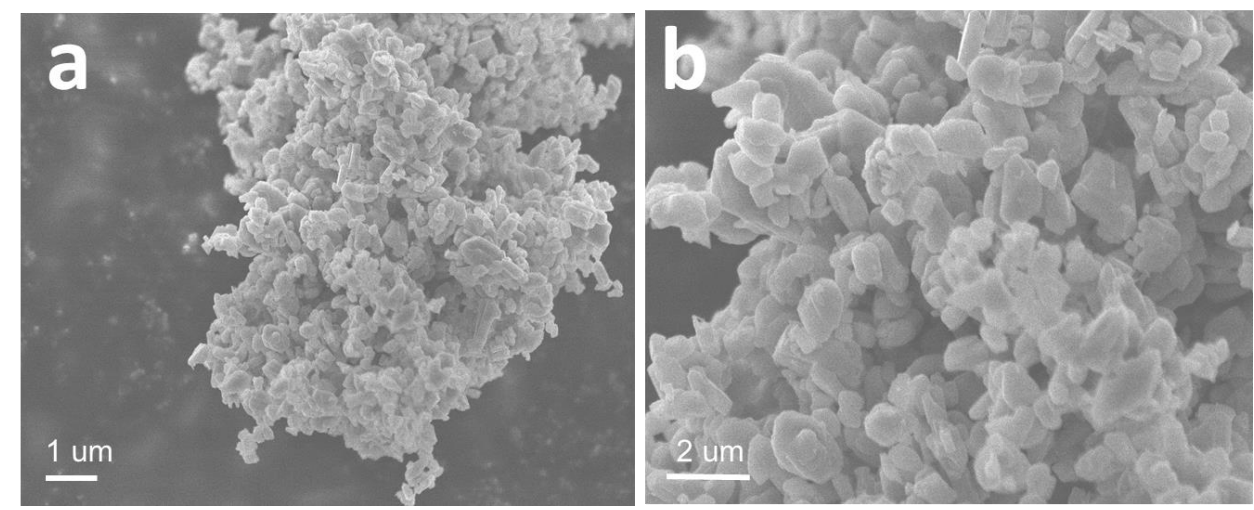

Figure S4. (a, b) SEM images of $\mathrm{MoO}_{3} @ \mathrm{MoO}_{2}-500$ sample without rGO at different magnifications. It is clear that the $\mathrm{MoO}_{3} @ \mathrm{MoO}_{2}$ heterostructure particles suffer from serious aggregation without rGO support. 

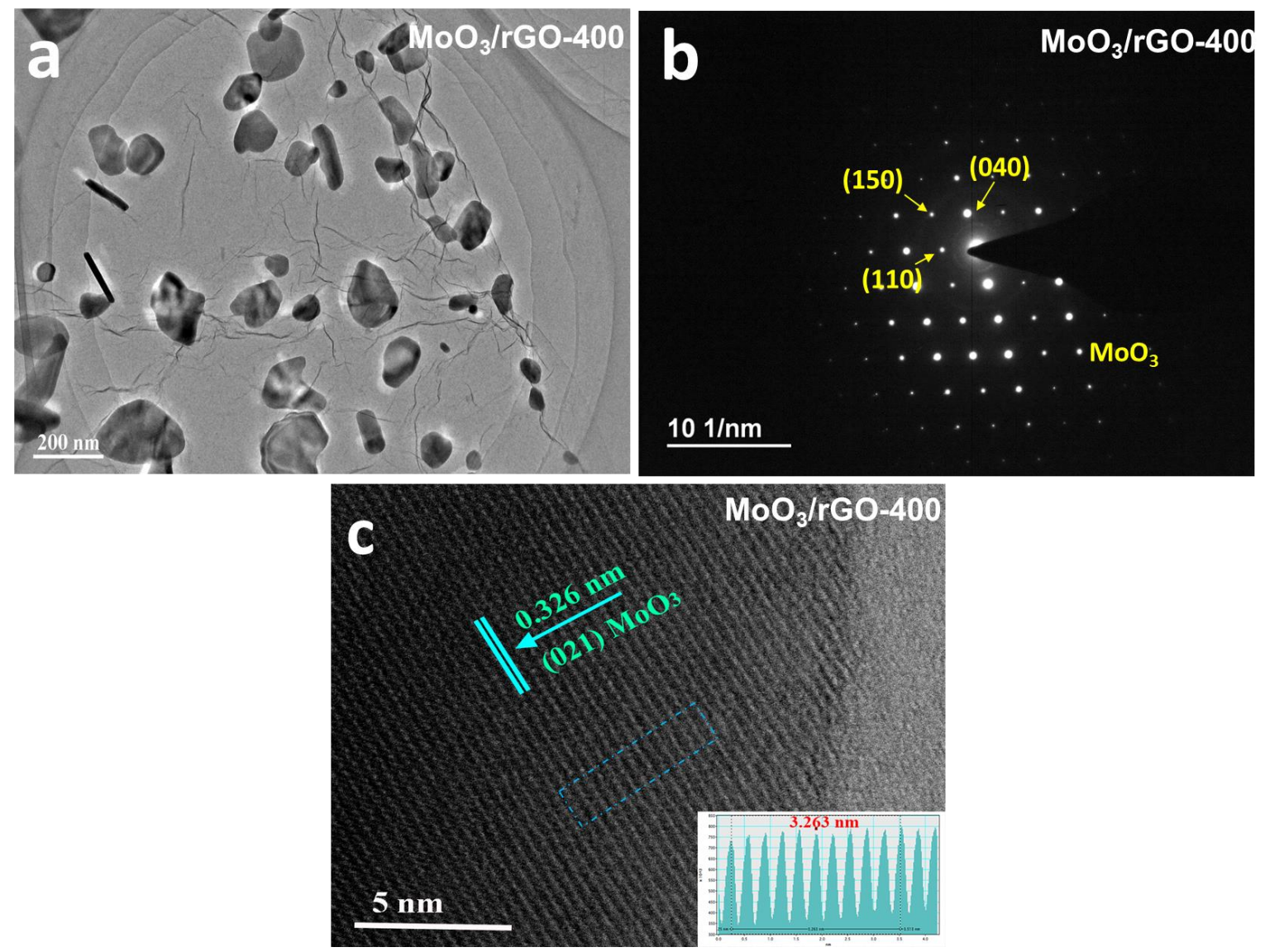

Figure S5. Morphology of $\mathrm{MoO}_{3} / \mathrm{rGO}-400$ sheets. (a) TEM image of $\mathrm{MoO}_{3} / \mathrm{rGO}-400$ sheets.

(b) SAED pattern of the $\mathrm{MoO}_{3} / \mathrm{rGO}-400$ sample with the zone axis of [00-1]. (c) HRTEM image of $\mathrm{MoO}_{3} / \mathrm{rGO}-400$ sample (inset: measurement of the lattice spacing, evaluated as $0.326 \mathrm{~nm}$ ). 

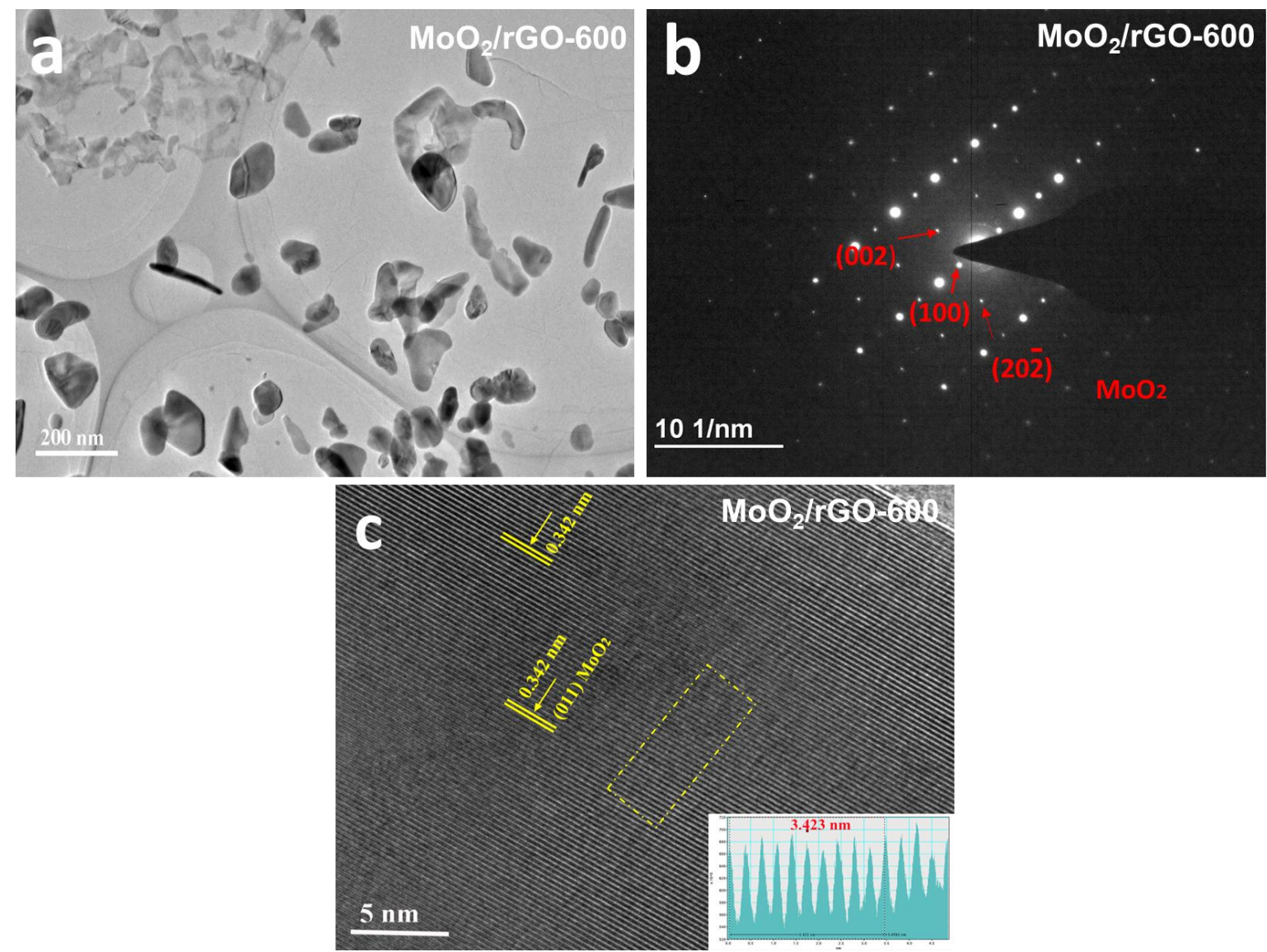

Figure S6. Morphology of $\mathrm{MoO}_{2} / \mathrm{rGO}-600$ sheets. (a) TEM image of $\mathrm{MoO}_{2} / \mathrm{rGO}-600$ sheets.

(b) SAED pattern of $\mathrm{MoO}_{2} / \mathrm{rGO}-600$ sample. (c) HRTEM image of $\mathrm{MoO}_{2} / \mathrm{rGO}-600$ sample (inset: measurement of lattice spacing, evaluated as $0.342 \mathrm{~nm}$ ). 


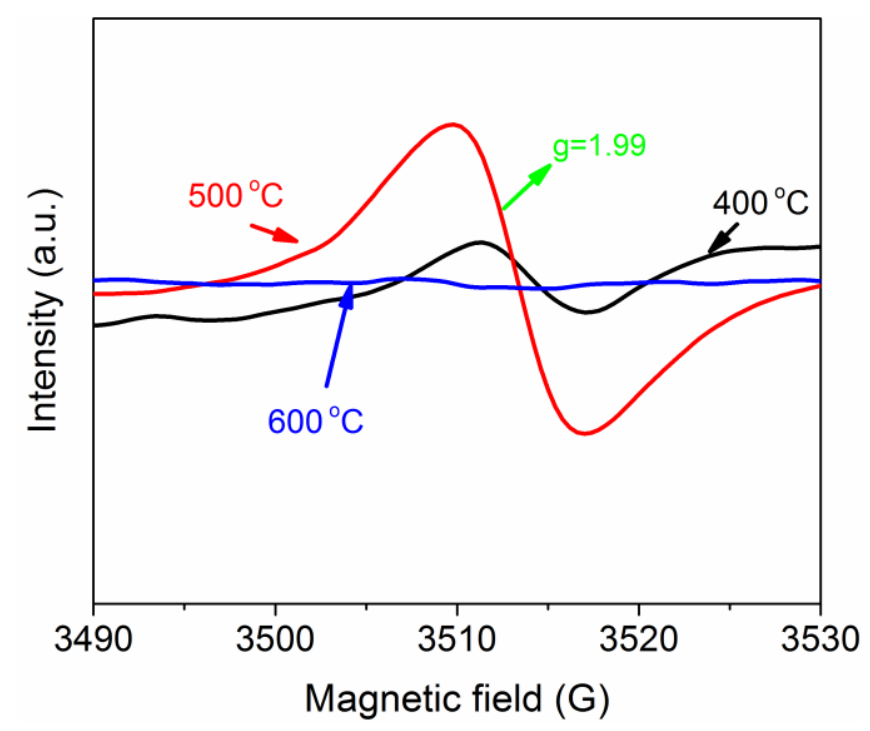

Figure S7. Electron paramagnetic resonance (EPR) spectrum of $\mathrm{MoO}_{3} / \mathrm{rGO}-400$, $\mathrm{MoO}_{3} @ \mathrm{MoO}_{2} / \mathrm{rGO}-500$, and $\mathrm{MoO}_{2} / \mathrm{rGO}-600$ samples. 

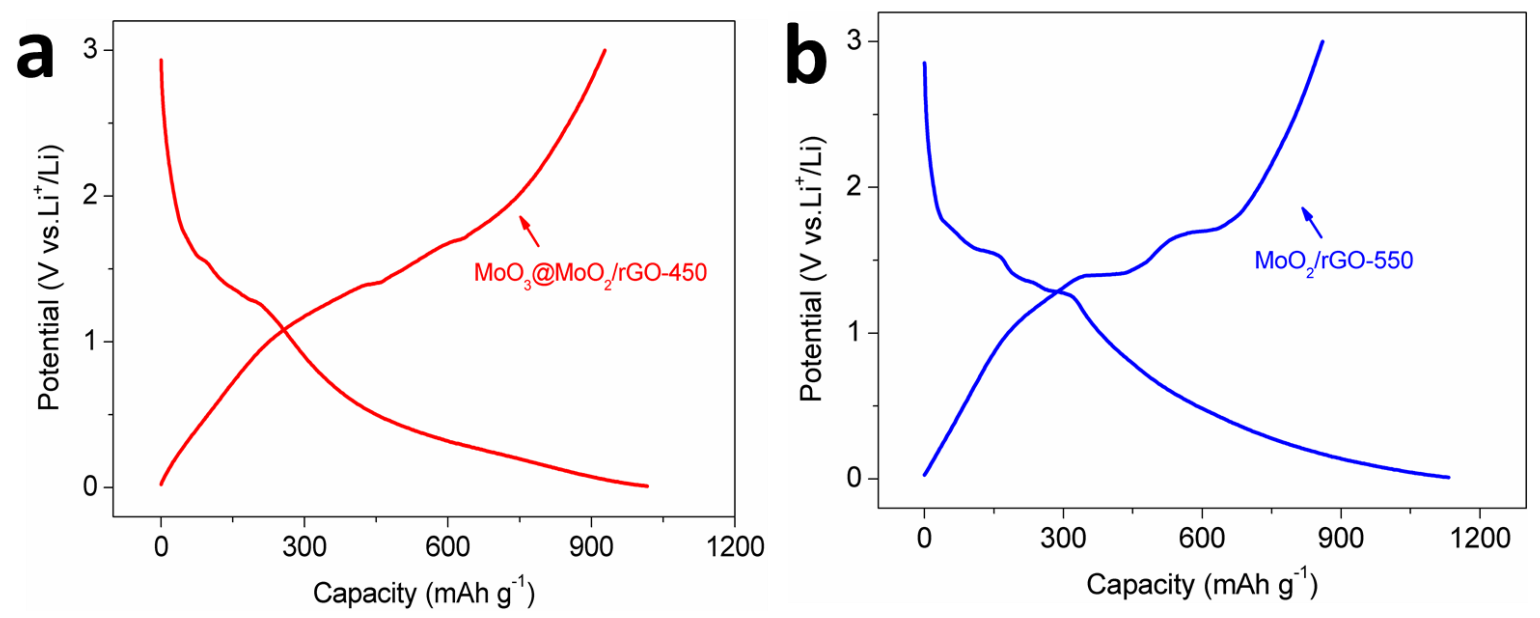

Figure S8. Typical galvanostatic discharge-charge profiles: (a) $\mathrm{MoO}_{3} @ \mathrm{MoO}_{2} / \mathrm{rGO}-450$, (b) $\mathrm{MoO}_{2} / \mathrm{rGO}-550$ electrodes. 


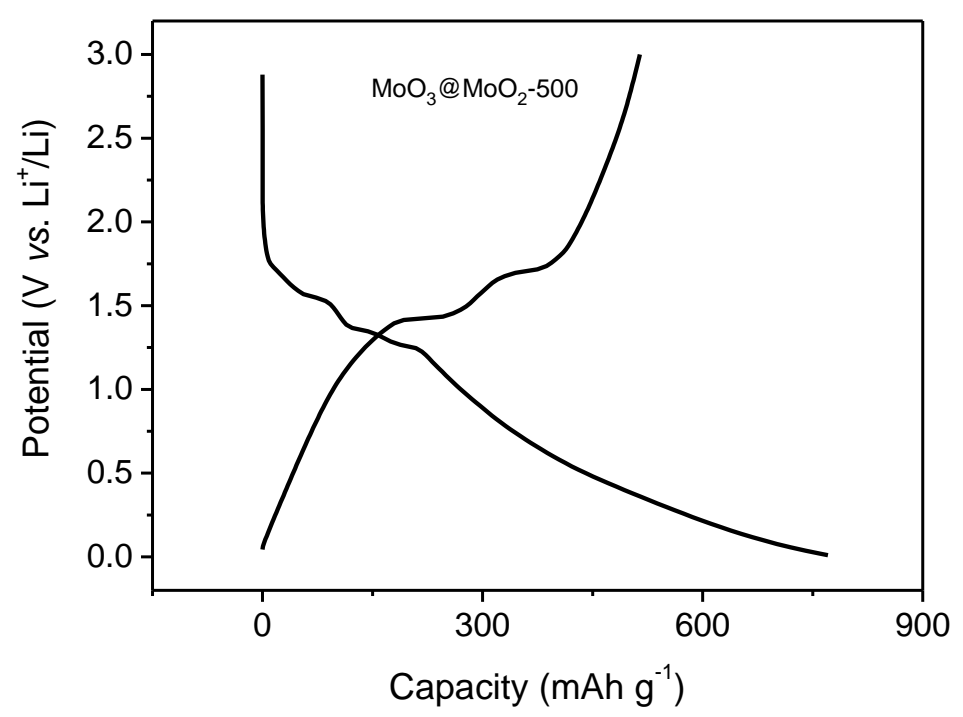

Figure S9. Typical charge-discharge curves of the $\mathrm{MoO}_{3} @ \mathrm{MoO}_{2}-500$ without $\mathrm{rGO}$. The discharge capacity of the $\mathrm{MoO}_{3} @ \mathrm{MoO}_{2}-500$ electrode is much lower than that with $\mathrm{rGO}$. 

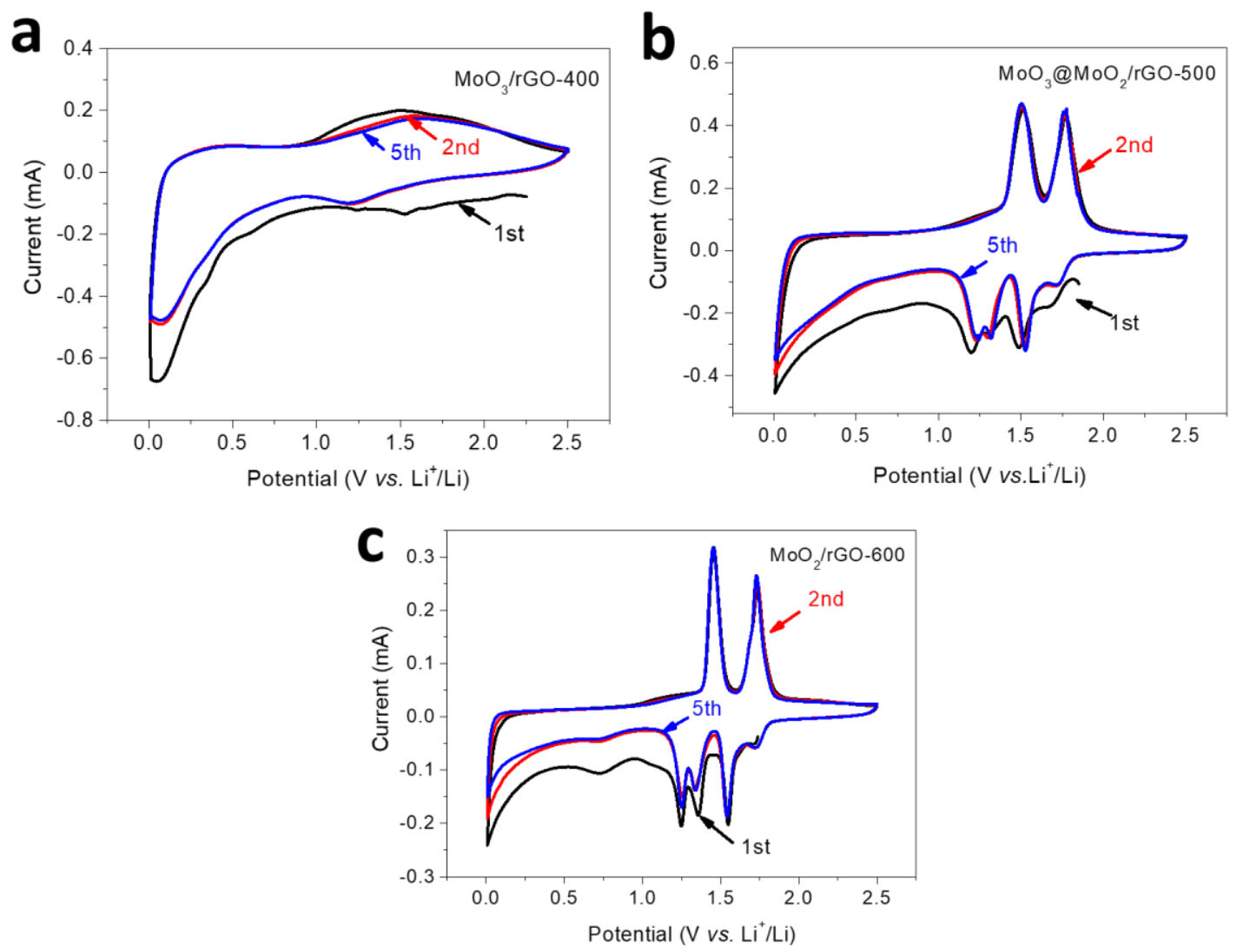

Figure S10. Cyclic voltammograms for the first, second, and fifth cycles: (a) $\mathrm{MoO}_{3} / \mathrm{rGO}-400$, (b) $\mathrm{MoO}_{3} @ \mathrm{MoO}_{2} / \mathrm{rGO}-500$, and (c) $\mathrm{MoO}_{2} / \mathrm{rGO}-600$ electrodes.

The cyclic voltammograms (CVs) of different samples for the first, second, and fifth cycles were collected at $0.5 \mathrm{mV} \mathrm{s}^{-1}$. In the first cycle of $\mathrm{MoO}_{3} / \mathrm{rGO}-400$ (Figure S6a), two broad and weak peaks at around 1.52 and $1.25 \mathrm{~V}$ are visible, corresponding to the intercalation of $\mathrm{Li}^{+}$ into $\left[\mathrm{MoO}_{6}\right]$ bi-layers to form $\mathrm{Li}_{x} \mathrm{MoO}_{3}\left(x_{\max }=1.5\right)$. In the subsequent lithiation process, another sharp peak appears below $0.4 \mathrm{~V}$, corresponding to the conversion reaction of $\mathrm{Li}_{x} \mathrm{MoO}_{3}{ }^{2}$ Overall, the Li storage reaction in $\mathrm{MoO}_{3}$ can be described as follows:

$$
\begin{aligned}
& \mathrm{MoO}_{3}+x \mathrm{Li}^{+}+x e^{-} \leftrightarrow \mathrm{Li}_{x} \mathrm{MoO}_{3}(0<x<1.5) \\
& \mathrm{Li}_{x} \mathrm{MoO}_{3}+(6-x) \mathrm{Li}^{+}+(6-x) e^{-} \leftrightarrow \mathrm{Mo}+3 \mathrm{Li}_{2} \mathrm{O}
\end{aligned}
$$


Due to the presence of $\mathrm{MoO}_{2}$, the $\mathrm{CV}$ curves of $\mathrm{MoO}_{3} @ \mathrm{MoO}_{2} / \mathrm{rGO}-500$ and $\mathrm{MoO}_{2} / \mathrm{rGO}-600$ are different from that of $\mathrm{MoO}_{3} / \mathrm{rGO}-400$ electrode. Three sharp reduction peaks located at approximately $1.25,1.31$, and $1.52 \mathrm{~V}$ can be observed (Figure S6b and S6c), which mainly arise from the phase transitions from the original monoclinic to the orthorhombic phase and then from the orthorhombic to the monoclinic phase in the Li insertion process. ${ }^{3}$ The reaction mechanism of $\mathrm{MoO}_{2}$ can be described as follows:

$$
\begin{aligned}
& \mathrm{MoO}_{2}+x \mathrm{Li}^{+}+x e^{-} \leftrightarrow \mathrm{Li}_{x} \mathrm{MoO}_{2}(0<x<0.98) \\
& \mathrm{Li}_{x} \mathrm{MoO}_{2}+y \mathrm{Li}^{+}+y e^{-} \leftrightarrow \mathrm{Li}_{(x+y)} \mathrm{MoO}_{2}(0<x, y<0.98) \\
& \mathrm{Li}_{0.98} \mathrm{MoO}_{3}+3.02 \mathrm{Li}^{+}+3.02 e^{-} \leftrightarrow \mathrm{Mo}+2 \mathrm{Li}_{2} \mathrm{O}
\end{aligned}
$$



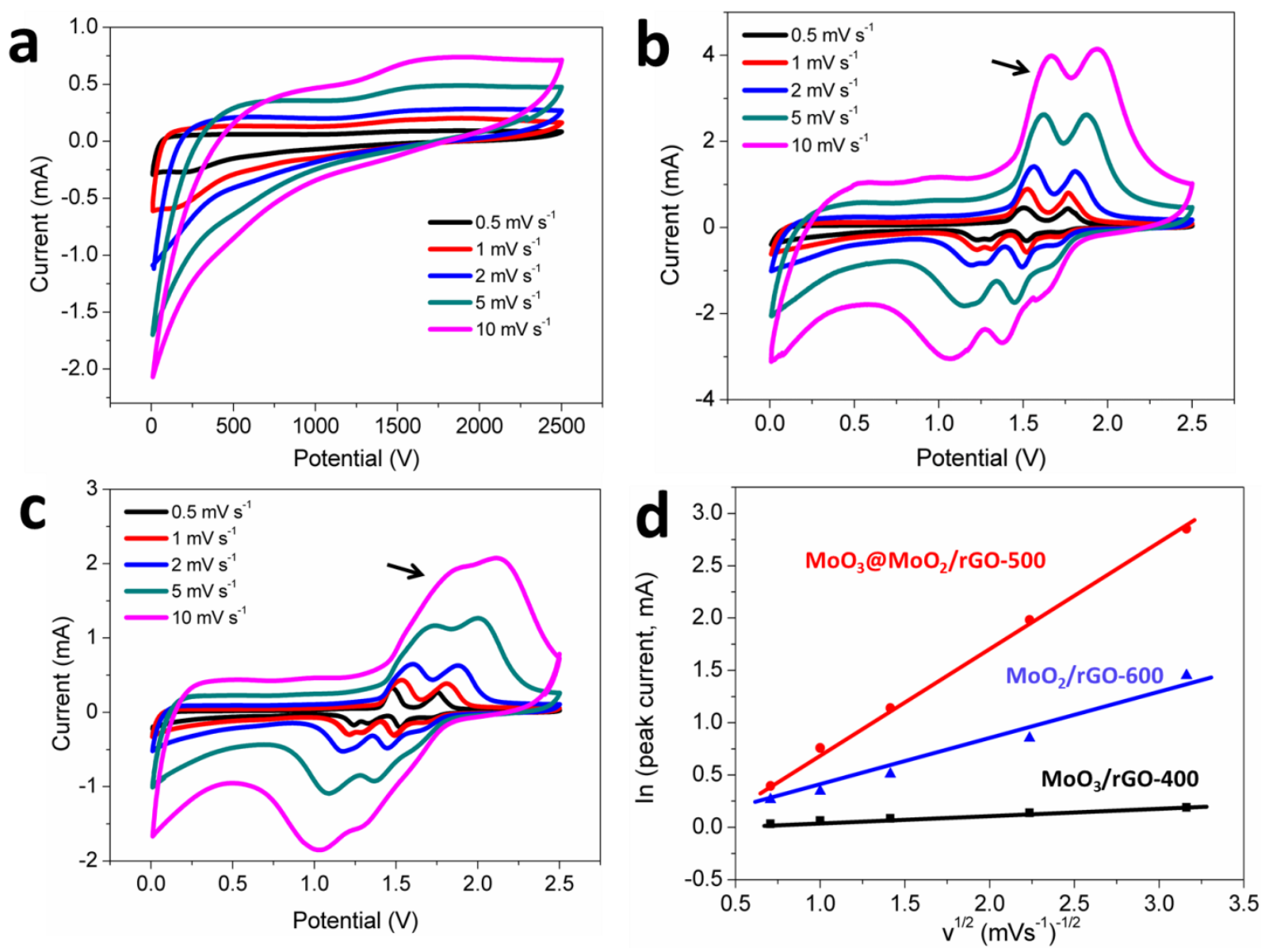

Figure S11. $\mathrm{CV}$ curves at various scan rates: (a) $\mathrm{MoO}_{3} / \mathrm{rGO}-400$ electrode, (b) $\mathrm{MoO}_{3} @ \mathrm{MoO}_{2} / \mathrm{rGO}-500$ electrode, (c) $\mathrm{MoO}_{2} / \mathrm{rGO}-600$ electrode. (d) The linear relationship between the peak current $\left(i_{p}\right)$ and the square root of the scan rate $\left(v^{1 / 2}\right)$ for the different electrodes. 

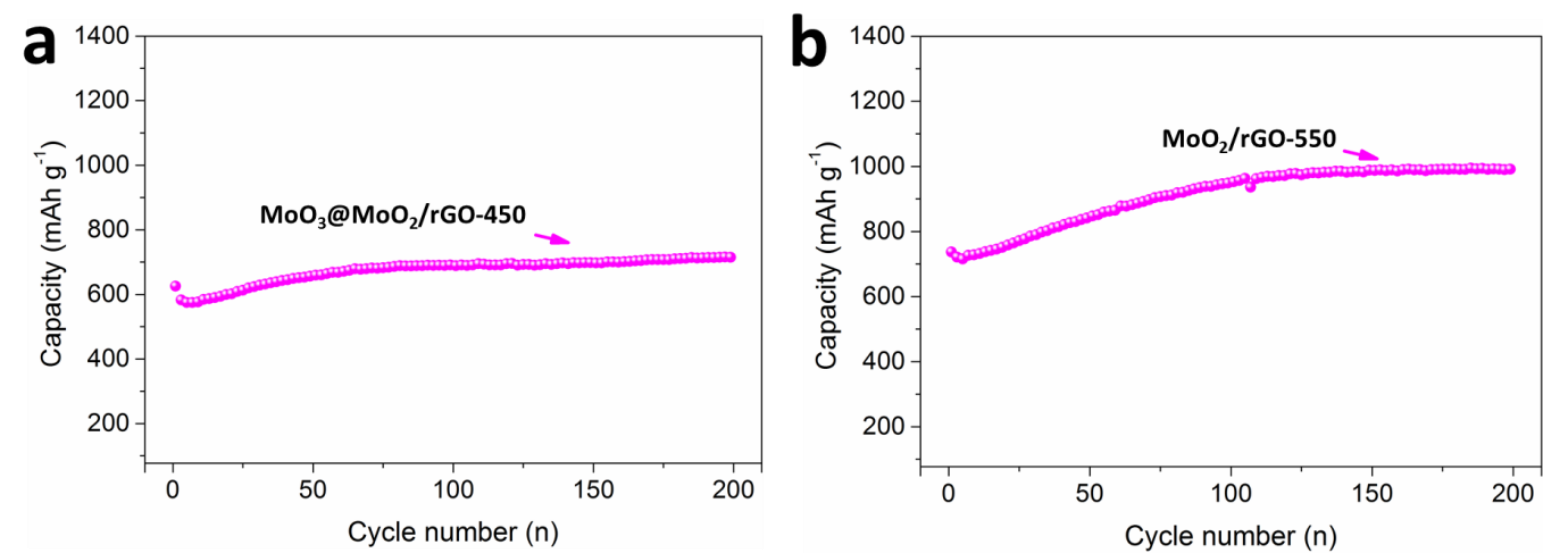

Figure S12. Cycling performance for 200 cycles at $2 \mathrm{~A} \mathrm{~g}^{-1}$ : (a) $\mathrm{MoO}_{3} @ \mathrm{MoO}_{2} / \mathrm{rGO}-450$, (b) $\mathrm{MoO}_{2} / \mathrm{rGO}-550$ electrodes. 


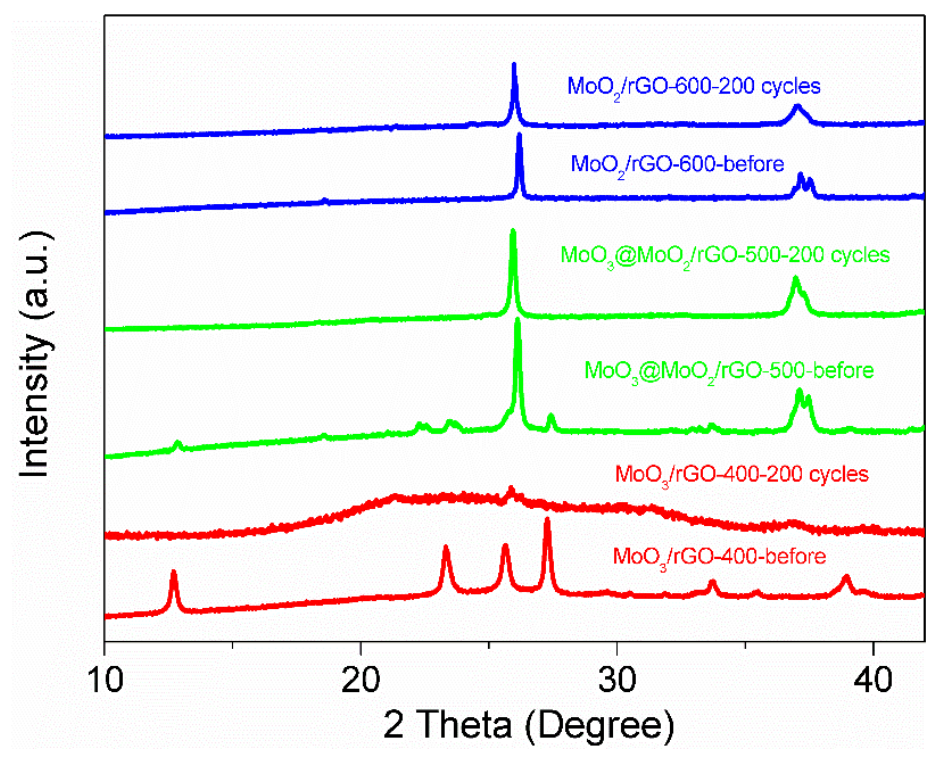

Figure S13. XRD pattern changes of $\mathrm{MoO}_{3} / \mathrm{rGO}-400, \mathrm{MoO}_{3} @ \mathrm{MoO}_{2} / \mathrm{rGO}-500$, and $\mathrm{MoO}_{2} / \mathrm{rGO}-600$ electrodes before cycling and after 200 cycles. 


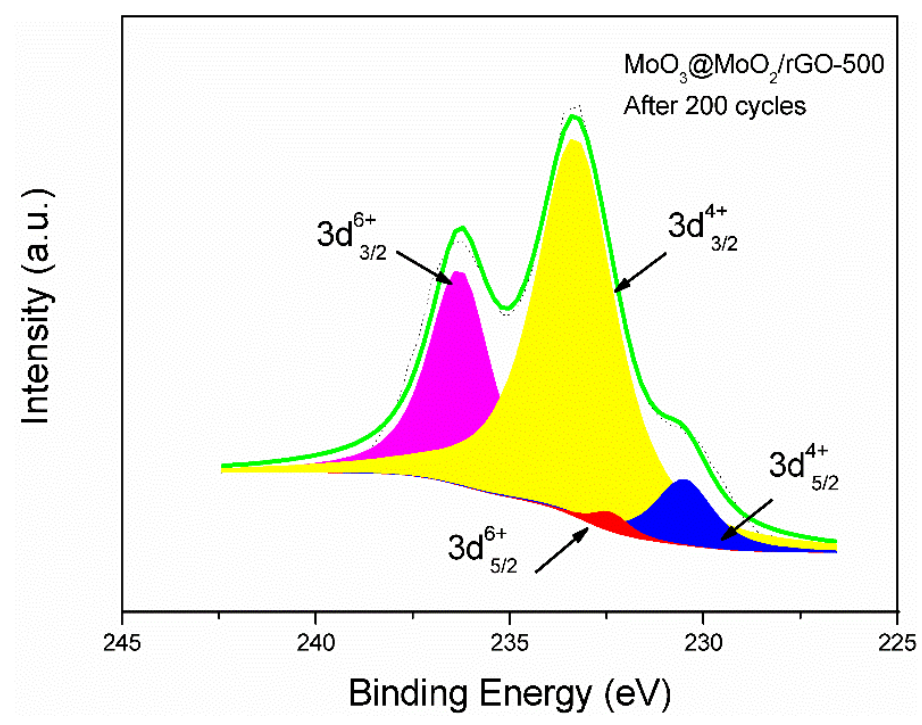

Figure S14. Mo 3d XPS spectrum of $\mathrm{MoO}_{3} @ \mathrm{MoO}_{2} / \mathrm{rGO}-500$ electrode after 200 cycles. 


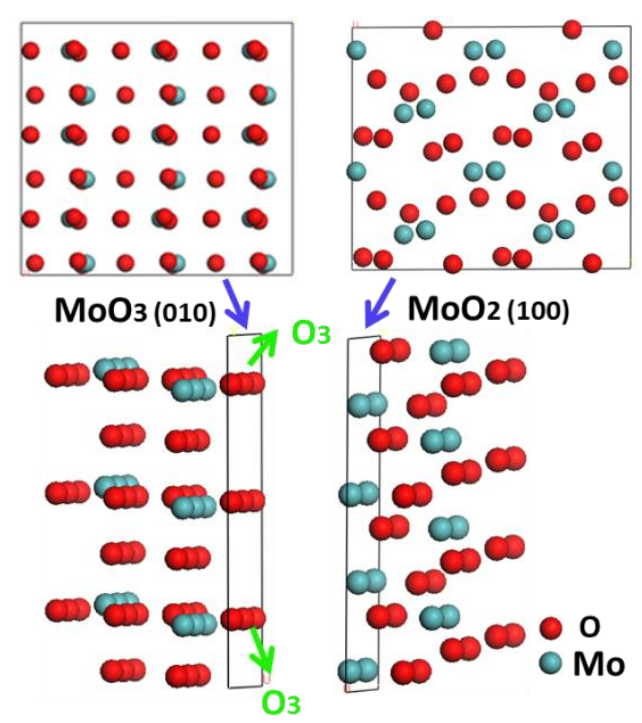

Interface

Figure S15. The models for the $\mathrm{MoO}_{3}(010)$ and $\mathrm{MoO}_{2}(100)$ slabs. According to the solidstate reaction kinetics of the reduction of $\alpha-\mathrm{MoO}_{3}$, the lattice oxygen $\mathrm{O}_{(3)}$ along the $(010)$ facet is reduced as the temperature increases, resulting in oxygen vacancies. ${ }^{4}$ The formation of oxygen vacancies at the $\mathrm{O}_{(1)}$ and $\mathrm{O}_{(2)}$ sites is significantly less favourable than at the $\mathrm{O}_{(3)}$ site. This is because the vacancy structure at the $\mathrm{O}_{(3)}$ site, where two polarons occupy the $\mathrm{d}_{x y}$ and $\mathrm{d}_{y z}$ orbitals of the five-fold coordinated $\mathrm{Mo}^{4+}$ ion at the defect, is $0.19 \mathrm{eV}$ higher in energy. ${ }^{5,6}$ The re-organization of lattice oxygen takes place in the $\mathrm{MoO}_{3}$ bulk along the [100] or [001] direction, forming defects in the structure, and the lattice oxygen at the surface of the (010) facet is replenished. This is because oxygen diffusion along the [100] or [001] directions in the $\mathrm{MoO}_{3}$ layered structure is much faster than parallel to the layers $([010]$ direction). After a certain concentration of oxygen vacancies in the $\mathrm{MoO}_{3}$ structure has been exceeded, the oxygen vacancies are consumed by forming intermediate phase $\mathrm{Mo}_{4} \mathrm{O}_{11}$ $\left(3 \mathrm{MoO}_{3} \cdot \mathrm{MoO}_{2}\right)$ impurities, which serve as nucleation sites for the rapid formation of $\mathrm{MoO}_{2}$ crystallites. The mechanism for the formation of $\mathrm{MoO}_{2}$ structure seems to be strongly dependent on the layered structure in the [010] direction of $\mathrm{MoO}_{3}$, seeing that the various 
orientations of $\mathrm{MoO}_{2}$ crystallites correspond to some boundary planes in $\mathrm{MoO}_{2}$, which have a structure very close to the (010) planes in the semi-layer. ${ }^{7}$ The reduction brings about the collapse of the successive (010) planes of $\mathrm{MoO}_{3}$. In this transformation, the <100> rows in $\mathrm{MoO}_{2}$, constituted by strongly linked elements (edge-sharing $\mathrm{MoO}_{6}$ octahedra) are found to be arranged in some directions perpendicular or very oblique with respect to the initial $(010)$ surface of $\mathrm{MoO}_{3}$. Specifically, the (010) lattice plane of $\mathrm{MoO}_{3}$ is converted into the (100) facet of $\mathrm{MoO}_{2}$ as the temperature increases. The lattice plane size details: $\mathrm{MoO}_{3}(010): a=$ $11.0892 \AA, b=11.8884 \AA ; \mathrm{MoO}_{2}(100): a=9.7132 \AA, b=11.0892 \AA$. 

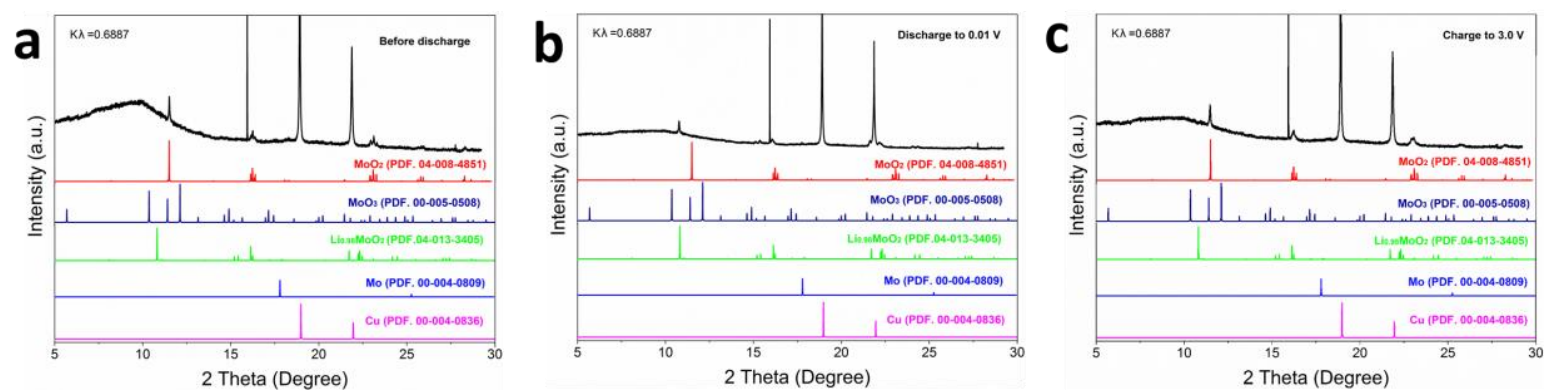

Figure S16. In-operando synchrotron XRPD data for $\mathrm{MoO}_{3} @ \mathrm{MoO}_{2} / \mathrm{rGO}-500$ electrode: (a) before discharge, (b) after discharge to $0.01 \mathrm{~V}$, and (c) after charge to $3.0 \mathrm{~V}$. Before discharge, the XRPD pattern matches well with $\mathrm{MoO}_{2}(\mathrm{~K} \lambda=0.6887 \AA)$. The main peaks of the XRPD pattern match ideally with $\mathrm{Li}_{0.98} \mathrm{MoO}_{2}$ on discharging to $0.01 \mathrm{~V}$. In the meantime, a small peak located at about $17.9^{\circ}$ can be observed, which means that the $\mathrm{MoO}_{3} @ \mathrm{MoO}_{2}$ heterostructures have been partially converted into Mo. When the cell is charged to $3.0 \mathrm{~V}$, the XRPD pattern shows similar peaks to the original pattern, indicating the good phase reversibility of $\mathrm{MoO}_{2}$, which helps to relieve the pulverization of $\alpha-\mathrm{MoO}_{3}$. 

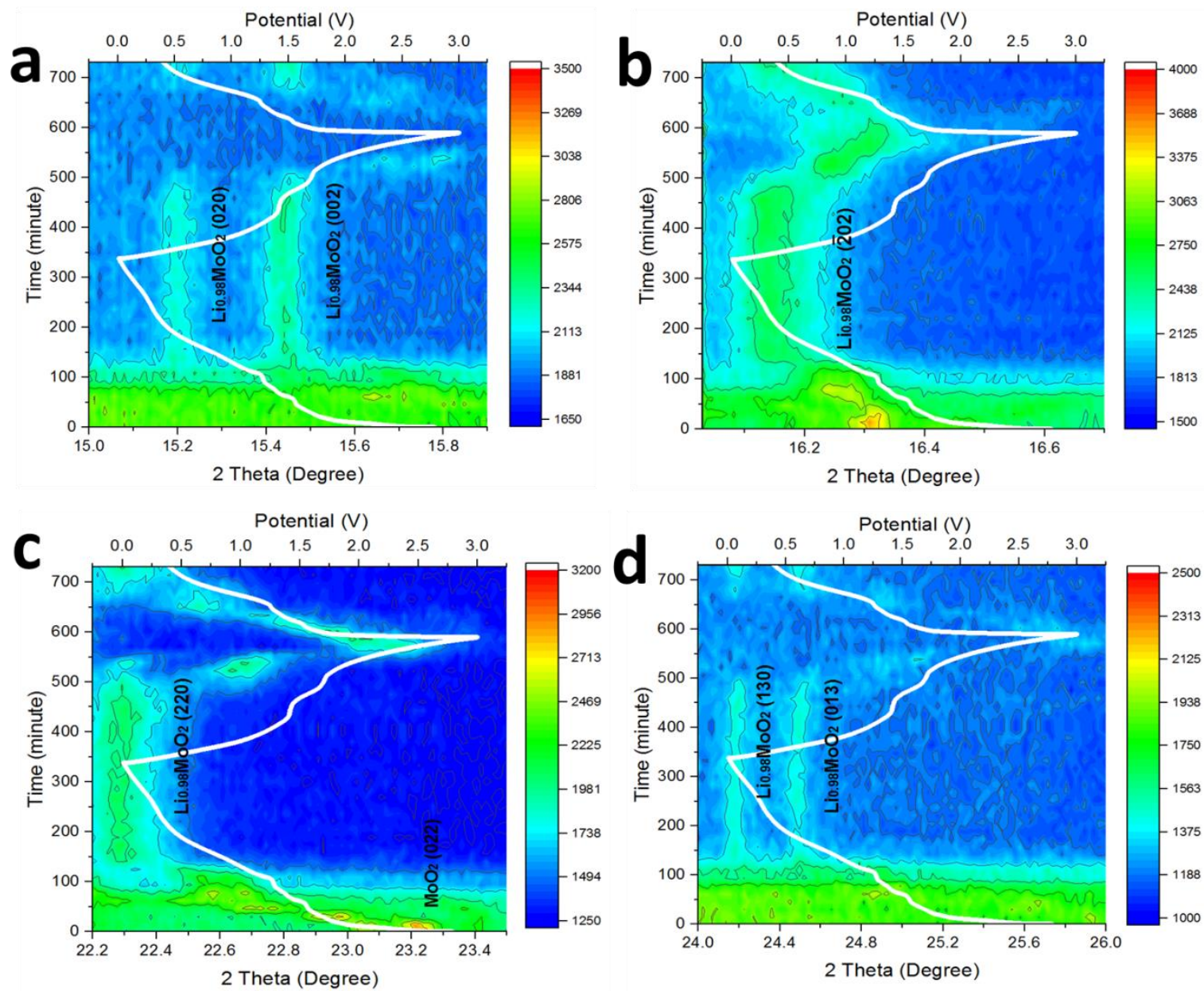

Figure S17. Contour plots of the in-operando synchrotron XRPD data for $\mathrm{MoO}_{3} @ \mathrm{MoO}_{2} / \mathrm{rGO}-500$ electrode in different degree ranges: (a) $15.0^{\circ}-15.9^{\circ}$, where the $(020)$ and (002) peaks of $\mathrm{Li}_{0.98} \mathrm{MoO}_{2}$ appear in the discharge process; (b) $16.0^{\circ}-16.8^{\circ}$, where the ( $\overline{2} 02$ ) peak of $\mathrm{Li}_{0.98} \mathrm{MoO}_{2}$ appears; (c) $22.2^{\circ}-23.6^{\circ}$, where the (022) peak of $\mathrm{MoO}_{2}$ is converted to the (220) peak of $\mathrm{Li}_{0.98} \mathrm{MoO}_{2}$; and (d) $24.0^{\circ}-26.0^{\circ}$. (Note that the synchrotron coin cell was perpendicularly placed on the sample stage, so that the excess electrolyte flowed to the bottom of the cell due to gravity, resulting in a significant drop of the background signal) 


\section{References}

1. Gao, H.; Zhou, T.; Zheng, Y.; Zhang, Q.; Liu, Y.; Chen, J.; Liu, H.; Guo, Z., Cos Quantum Dot Nanoclusters for High-Energy Potassium-Ion Batteries. Adv. Funct. Mater. 2017, 27, 1702634.

2. Mai, L. Q.; Hu, B.; Chen, W.; Qi, Y.; Lao, C.; Yang, R.; Dai, Y.; Wang, Z. L., Lithiated $\mathrm{MoO}_{3}$ Nanobelts with Greatly Improved Performance for Lithium Batteries. Adv. Mater. 2007, 19, 3712-3716.

3. Dahn, J. R.; McKinnon, W. R., Structure and Electrochemistry of $\mathrm{Li}_{\mathrm{x}} \mathrm{MoO}_{2}$. Solid State Ionics 1987, 23, 1-7.

4. Lalik, E., Kinetic Analysis of Reduction of $\mathrm{MoO}_{3}$ to $\mathrm{MoO}_{2}$. Catal. Today 2011, 169, $85-92$.

5. Bhaskar, A.; Deepa, M.; Rao, T. N.; Varadaraju, U. V., Enhanced Nanoscale Conduction Capability of a $\mathrm{MoO}_{2} /$ Graphene Composite for High Performance Anodes in Lithium Ion Batteries. J. Power Sources 2012, 216, 169-178.

6. Dieterle, M.; Weinberg, G.; Mestl, G., Raman Spectroscopy of Molybdenum Oxides Part I. Structural Characterization of Oxygen Defects in $\mathrm{MoO}_{3-\mathrm{x}}$ by DR UV/Vis, Raman Spectroscopy and X-Ray Diffraction. Phys. Chem. Chem. Phys. 2002, 4, 812-821.

7. Scanlon, D. O.; Watson, G. W.; Payne, D. J.; Atkinson, G. R.; Egdell, R. G.; Law, D. S. L., Theoretical and Experimental Study of the Electronic Structures of $\mathrm{MoO}_{3}$ and $\mathrm{MoO}_{2}$. J. Phys. Chem. C. 2010, 114, 4636-4645. 